BNL 50580

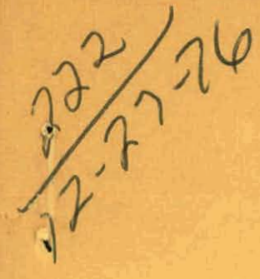

BROOKHAVEN NATIONAL LABORATORY REGIONAL ENERGY STUDIES PROGRAM
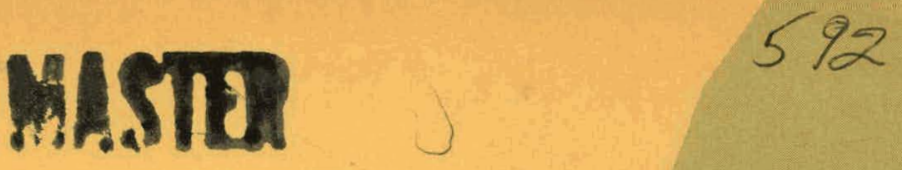

\title{
THE ENERGY SITUATION IN NEW ENGLAND
}

November 1976

\section{POLICY ANALYSIS DIVISION}

NATIONAL CENTER FOR ANALYSIS OF ENERGY SYSTEMS BROOKHAVEN NATIONAL LABORATORY UPTON, NEW YORK II973

Prepared for the UNITED STATES ENERGY RESEARCH AND DEVELOPMENT ADMINISTRATION 


\section{DISCLAIMER}

This report was prepared as an account of work sponsored by an agency of the United States Government. Neither the United States Government nor any agency Thereof, nor any of their employees, makes any warranty, express or implied, or assumes any legal liability or responsibility for the accuracy, completeness, or usefulness of any information, apparatus, product, or process disclosed, or represents that its use would not infringe privately owned rights. Reference herein to any specific commercial product, process, or service by trade name, trademark, manufacturer, or otherwise does not necessarily constitute or imply its endorsement, recommendation, or favoring by the United States Government or any agency thereof. The views and opinions of authors expressed herein do not necessarily state or reflect those of the United States Government or any agency thereof. 


\section{DISCLAIMER}

Portions of this document may be illegible in electronic image products. Images are produced from the best available original document. 


\title{
THE ENERGY SITUATION IN NEW ENGLAND
}

\author{
Joel P. Brainard, James S. Munson and Phillp F. Palmedo
}

With contributions by

edward Kaplan, John C. Lee and Samuel C. Morris III

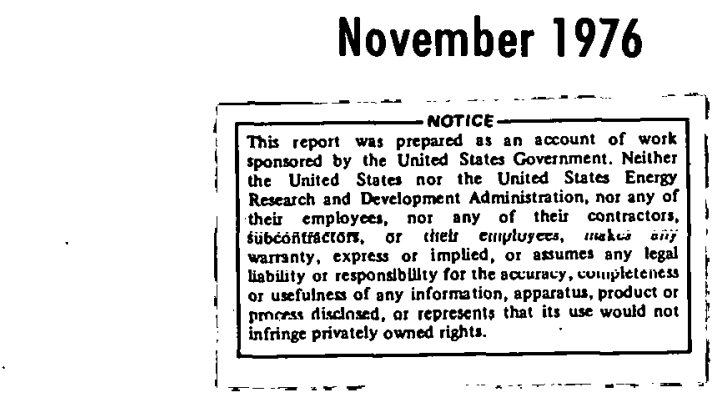

POLICY ANALYSIS DIVISION

NATIONAL CENTER FOR ANALYSIS OF ENERGY SYSTEMS

BROOKHAVEN NATIONAL LABORATORY

ASSOCIATED UNIVERSITIES, INC.

UNDER CONTRACT NO. EY-76-C-02-0016 WITH THE

UNITED STATES ENERGY RESEARCH AND DEVELOPMENT ADMINISTRATION 


\section{N O T I C E}

This report was prepared as an account of work sponsored by the United States Government. Neither the United States nor the United States Energy Research and Development Administration, nor any of their employees, nor any of their contractors,

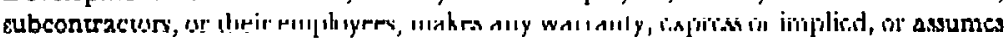
any.legal liability or-responsibility for the accuracy, completeness or usefulness of any information, apparatus, product or process disclosed, or represents that its use would not infringe privately owned rights.

Printed in the United States of America Available from

National Technical Information Service

U.S. Department of Commerce

j285 Port Ruyal Road

Springfield, VA 22161

Price: Printed Copy $\$ 4.50$; Micrufiche $\$ 3.00$

November 1976

2450 copies 


\section{Acknowledgements}

A large number of individuals and groups contributed to the preparation of this report. . In all of the New England states members of state governments were generous and frank in their discussion of energy issues. At the regional level conversations with Joe Vitka of the New England Regional Commission, Peter Clark of the New England Energy Policy Council and Sara Schneeberg of the New England River Basins Commission were particularly helpful. Linda Mansfield of the Federal Energy Administration Region I office was of great help in providing data and interpretations of those data for the region.

We are also grateful to Gracie Hemphill and Susan Huskinson of ERDA and Robert Atcher of Argonne National Laboratory for their advice before and during the preparation of the report. At Brookhaven, Carl Thien and Beverly Goldstein prepared an extensive report of pertinent newspaper clippings that was used as the basis of the clipping section of this report. Robert Stern, Donna Visone and Georgia Irving contributed. invaluably to the preparation of the report. 


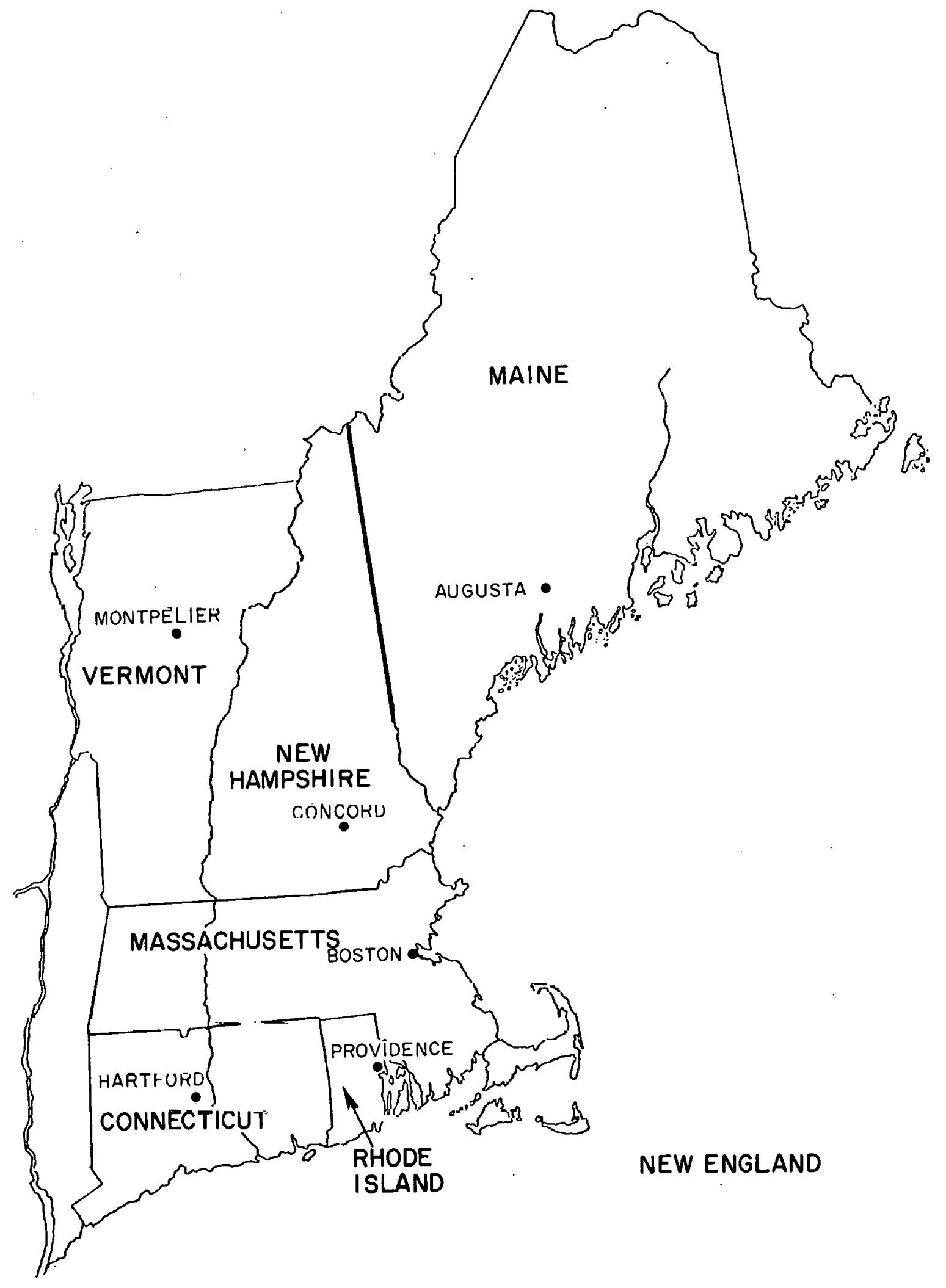




\section{Table of Contents}

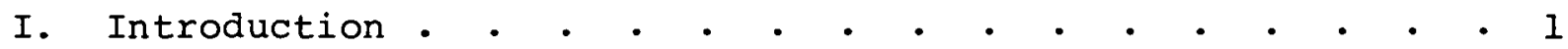

II. The Energy Situation in New England
A. Introduction
B. Current Energy Consumption Patterns
C. Energy Supply
D. Trends and Projections of the Demand for Energy.
E. Energy Prices
F. Energy Sources Indigenous to the Region
G. Environmental Issues.

III. Regional Energy Issues
A. Introduction
B. Energy Policy
C. Fossil Fuels
D. Nuclear
E. Solar and Alternative Energy Resources.
F. Conservation
G. Environmental Protection
H. Consumer Issues
I. Public Power

Appendix A: A New England Energy Policy 


\section{INTRODUCTION}

This briefing book is designed to give a concise overview of the facts of the energy situation in New England and of attitudes within the region towards current energy issues. It was prepared by the Policy Analysis Division of the National Center for Aralysis of Energy Systems at Brookhaven National Laboratory in preparation for a meeting in Boston at the end of November, 1976 at which the Administrator of the Energy Research and Development Administration and his staff will present ERDA's research and development plans and policies for public discussion.

Many of the central problems of U.S. energy policy are manifested in the region in a magnified form. The region entered the period of energy shortages and increasing prices in an economically declining condition. Manufacturing activity and jobs were being lost to other regions of the country and personal income was increasing at significantly slower rates. Energy prices were already high in 1970 , 30\% higher than the rest of the country. The difference would increase to $38 \%$ by 1974 .

With essentially no indigeneous energy resources New England is an energy importing region. For various reasons it is also more dependent on petroleum than other regions of the country and at the same time distant from domestic petroleum producing regions. The result is that over $60 \%$ of the fuels it consumes is imported from abroad.

Although the future supply of energy to the region is critically dependent on energy resource policies, policies related for example to coal and oil shale development, the region's concerns cluster around policies and technologies that are perceived to have a more direct impact on its energy welfare. Thus, energy conservation, solar energy, nuclear power, offshore oil development and, in general, the price of energy to the region are paramount issues of concern and debate. 
These issues are explored in more detail in the body of this report. It should be borne in mind, however, that the energy situation changes rapidly. The current version was completed in October 1976 and, particularly in terms of the representation of regional concerns and attitudes, should be used with caution as time progresses from that point. 
II. THE ENERGY SITUATION IN NEW ENGLAND

\section{A. Introduction}

In this section we present an overview of the past and present energy supply and demand situation in New England. In particular, we document some of the differences that exist between the energy situation in this region and other regions of the country. We find that those differences are large and that many of the central problems of the U.S. energy situation exist in magnified forms in the northeast corner of the nation.

Analysis of the energy problems of New England and finding solutions to these problems is complicated by the varied nature of many of the basic characteristics that directly or indirectly affect energy use in the region. For example, the number of degree days per year in northern Maine is nearly as high as in the coldest regions in the lower 48 states, while a relatively moderate climate prevails in the southern coastal areas of New England. Population densities also vary widely from the heavily populated urban areas to the sparsely settled rural counties. Even on a state basis, population densities in New England range from slightly more than half to nearly 13 times the U.S. average. Such variations mean that energy policies appropriate for one area in the region may be inappropriate for another.

Per capita income also varies widely in the region as can be seen in Figure 1. While the region had an average per capita income close to 58 higher than the national average in 1974, average per capita income in Connecticut was about $19 \%$ above that of the U.S. while income in Maine was about $18 \%$ below the national average. During the period 1970 to 1974 when per capita income in the U.S. grew at about $8.2 \%$ per year, income in most states in New England grew at substantially lower rates. Only in Vermont, which had one of the lowest average per capita income levels in New England, did the growth rate exceed that of the nation. 
Figure 1

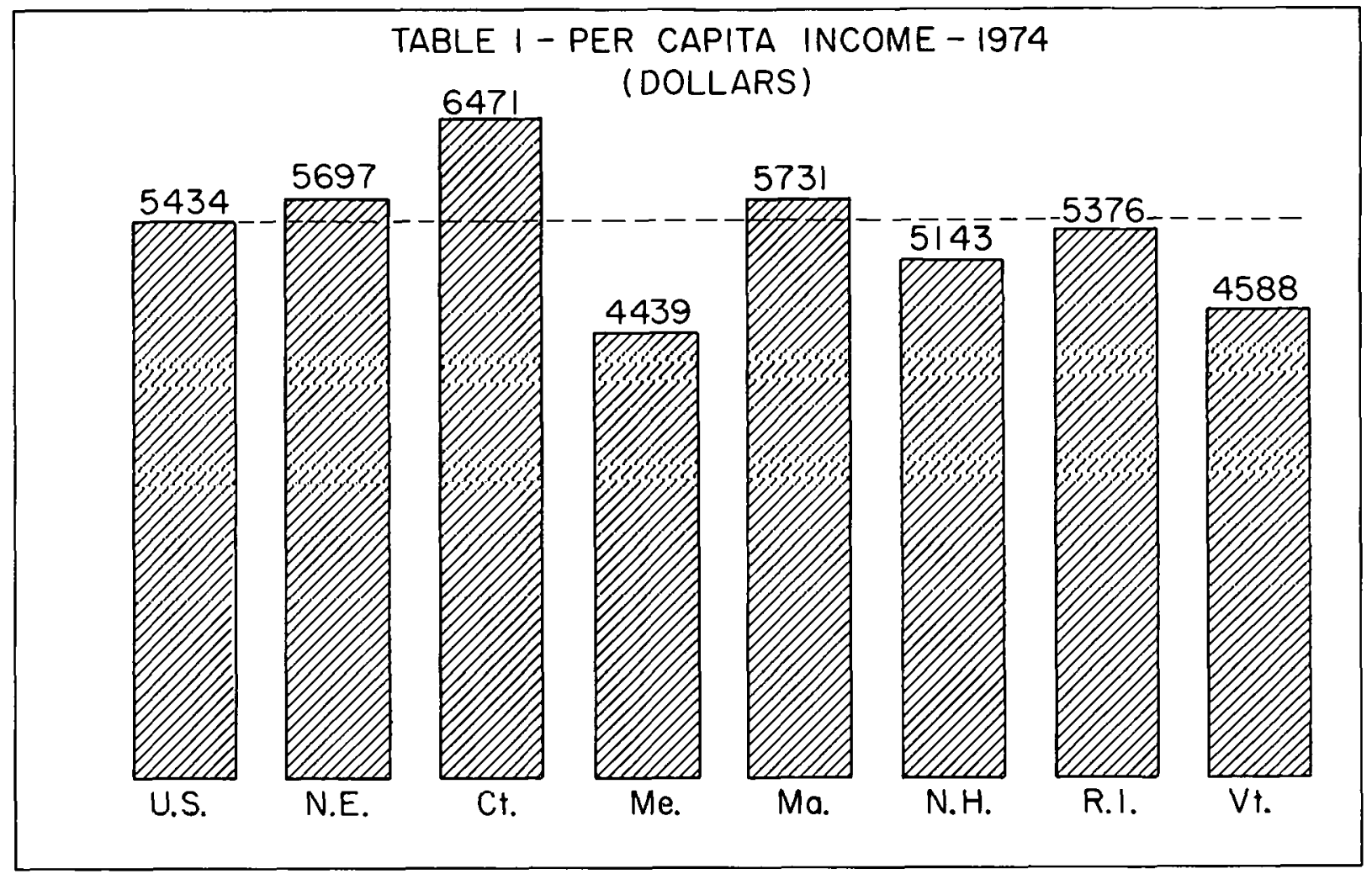

Despite the diversity that exists throughout New England, there are many common elements among the states in the region which relate to the demand for energy and its sources of supply. As we will discuss shortly in more detail, states in New England are all heavily dependent on petroleum products for energy and almost all of the petroleum used in New England had its origin in a foreign country. Thus, in addition to the presentation of basic statistics on energy use on a state by state basis, we have found it useful to discuss many of the common characteristics on a regional basis. 


\section{B. Current Energy Consumption Patterns}

The basic statistics on recent levels of energy consumption in the New England region and each state in the region are set forth in Tables 1, 2, and 3.* Table 1 shows the net annual energy consumption by fuel type for the New England States and the region in 1974. This table includes net electricity consumption, but not the energy resources used to generate electricity. Table 2 shows the resources used by the electric utilities in the region, and Table 3 shows the energy consumed by sector. On the basis of end use, New England consumes approximately $4.2 \%$ of the energy used in the country.

Energy consumption by sector on a per capita basis is shown in Figure 2 for 1972 and 1974. On a per capita basis, net energy consumption in 1974 in New England was approximately 27\% lower than the national average. In terms of gross energy resource consumption, the difference is slightly greater; New England's per capita consumption level was approximately 29 \% lower than the national average. It is clear from Figure 2 that the lower level of per capita energy consumption in New England relative to the United States results from a much lower energy consumption, on a per capita basis, in

\footnotetext{
* Many different sources of data were relied on in preparing this section. Different sources typically follow different conventions when categorizing data. Thus, it is frequently inappropriate to compare data from different sources without first making adjustments which compensate for major differences in the way the data were collected and processed. For example, the FEA "Son of Strawman" collection of data on energy use in the industrial sector does not include estimates of the energy resources used for feedstocks in this sector, whereas the Bureau of Mines does include such estimates in its data. Where we present data for comparison purposes, we have attempted to put the data on a consistent basis.
} 
Table 1

Net Annual Energy Consumption - 1974

$\left(10^{12}\right.$ Btu)

\begin{tabular}{|c|c|c|c|c|c|c|c|c|c|c|c|c|}
\hline & State & Jasoline & $\begin{array}{l}\text { Gist. } \\
\text { oil }\end{array}$ & $\begin{array}{c}\text { Diesel } \\
\text { Oil } \\
\end{array}$ & $\begin{array}{l}\text { Resid. } \\
\text { Jil } \\
\end{array}$ & $\begin{array}{l}\text { Jet } \\
\text { Oil }\end{array}$ & $\begin{array}{l}\text { Natural } \\
\text { gas }\end{array}$ & $\begin{array}{l}\text { Liq. } \\
\text { Gases }\end{array}$ & Electricity & Coal & Other & Total \\
\hline & Connecticut & 155.8 & 113.6 & 15.4 & 71.9 & 10.7 & 68.6 & 8.0 & 6.4 .1 & 1.8 & 7.4 & 527.6 \\
\hline & Maine & 55.0 & 66.5 & 6.1 & 71.0 & 10.4 & 3.0 & 3.1 & 21.3 & 1.9 & 6.3 & 254.5 \\
\hline 1 & Massachusetts & 237.0 & 324.3 & 18.7 & 204.1 & 38.8 & 154.7 & 8.2 & 100.2 & 3.1 & 18.0 & 1156.9 \\
\hline a) & New Hampshire & 48.8 & 43.2 & 2.5 & $15 . c$ & 4.8 & 8.6 & 4.7 & 16.6 & $0: 3$ & 3.8 & 149.1 \\
\hline & Rhode Island & 46.5 & .43 .7 & 4.1 & $27 . \bar{z}$ & 0.7 & 22.6 & 1.6 & 15.5 & - & 11.3 & 173.3 \\
\hline & Vermont & 29.4 & 27.4 & 2.5 & $3 . \Xi$ & 0.6 & 2.5 & 2.8 & 13.6 & 0.3 & 0.7 & 80.1 \\
\hline & New England & $6 \leqslant 2.5$ & 618.7 & 45.3 & 393.4 & 66.0 & 260.1 & 28.4 & 223.2 & 7.4 & 47.5 & 2341.4 \\
\hline
\end{tabular}

Note: Totals dn not include utility use of petroleum or coal.

So:-rce: "Son cf Strawman" catz, FEA, April 1976. 
Table 2

Energy Resources Used By Electric Utilities - 1974 $\left(10^{12} \mathrm{Btu}\right)$

\begin{tabular}{|c|c|c|c|c|c|c|c|c|c|c|}
\hline 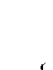 & States & Distillate Fuel & Residual Fuel & Natural Gas & Nuclear & Hydro & Coal, & Other & Total & $\begin{array}{l}\text { Total Sales } \\
\text { of Electricity }\end{array}$ \\
\hline & Connecticut & 2.8 & 158.4 & 0.6 & 83.7 & 4.4 & 3.8 & - & 263.6 & 64.1 \\
\hline & Maine & 0.6 & 25.0 & 0.4 & 37.5 & 18.2 & 0.0 & - & 81.8 & 21.3 \\
\hline & Massachusetts & 5.3 & 232.2 & 7.5 & 30.3 & 3.7 & 16.0 & - & 295.1 & 00.2 \\
\hline ' & New Hampshire & 0.5 & 14.2 & 1.0 & - & 13.4 & 24.6 & - & 53.8 & 16.6 \\
\hline$\sqrt{ }$ & Rhode Island & 0.3 & 11.2 & 2.0 & - & - & 1.6 & - & 15.1 & 15.5 \\
\hline & Vermont & 0.7 & - & 0.3 & 26.1 & 9.6 & 1.4 & - & 38.0 & 10.5 \\
\hline & New England & 10.2 & 451.0 & $11 . j$ & 177.6 & 49.4 & 47.4 & - & 747.3 & 228.2 \\
\hline
\end{tabular}

Source: "Son of Strawman" data, FEA, April 1976. 
Table 3

Energy Consumption by Sector - 1974

$$
\left(10^{12} \mathrm{Btu}\right)
$$

\begin{tabular}{|c|c|c|c|c|c|}
\hline State & $\begin{array}{c}\text { Residential \& } \\
\text { Conmercial } \\
\end{array}$ & Industrial & Transportation & Agriculture & Electric \\
\hline Connecticut & 240.7 & 88.0 & 193.0 & 4.9 & \\
\hline Maine & 102 & 57.6 & 93.0 & 1.8 & \\
\hline Massachusetts & 682.8 & 112.7 & 396.2 & 2.6 & \\
\hline New Hampshire & 72.9 & 19.5 & 54.9 & 0.8 & \\
\hline Rhode Island & 95 & $19 . ?$ & 57.4 & 0.8 & \\
\hline Vermont & 40.4 & 7.1 & 32.0 & $\underline{0.7}$ & 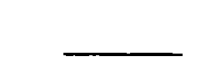 \\
\hline New Ergland & $1 \approx 33.8$ & 305.0 & 826.5 & 11.6 & 519.1 \\
\hline
\end{tabular}

Source: "Son of Strawman" data, FEA, April 1976. 
Figure 2

PER CAPITIA NET ENERGY

CONSUMPTION BY SECTOR

$$
\left[\begin{array}{ccc}
10^{6} & \text { BTU } \\
(\% & \text { OF } & \text { TOTAL })
\end{array}\right]
$$
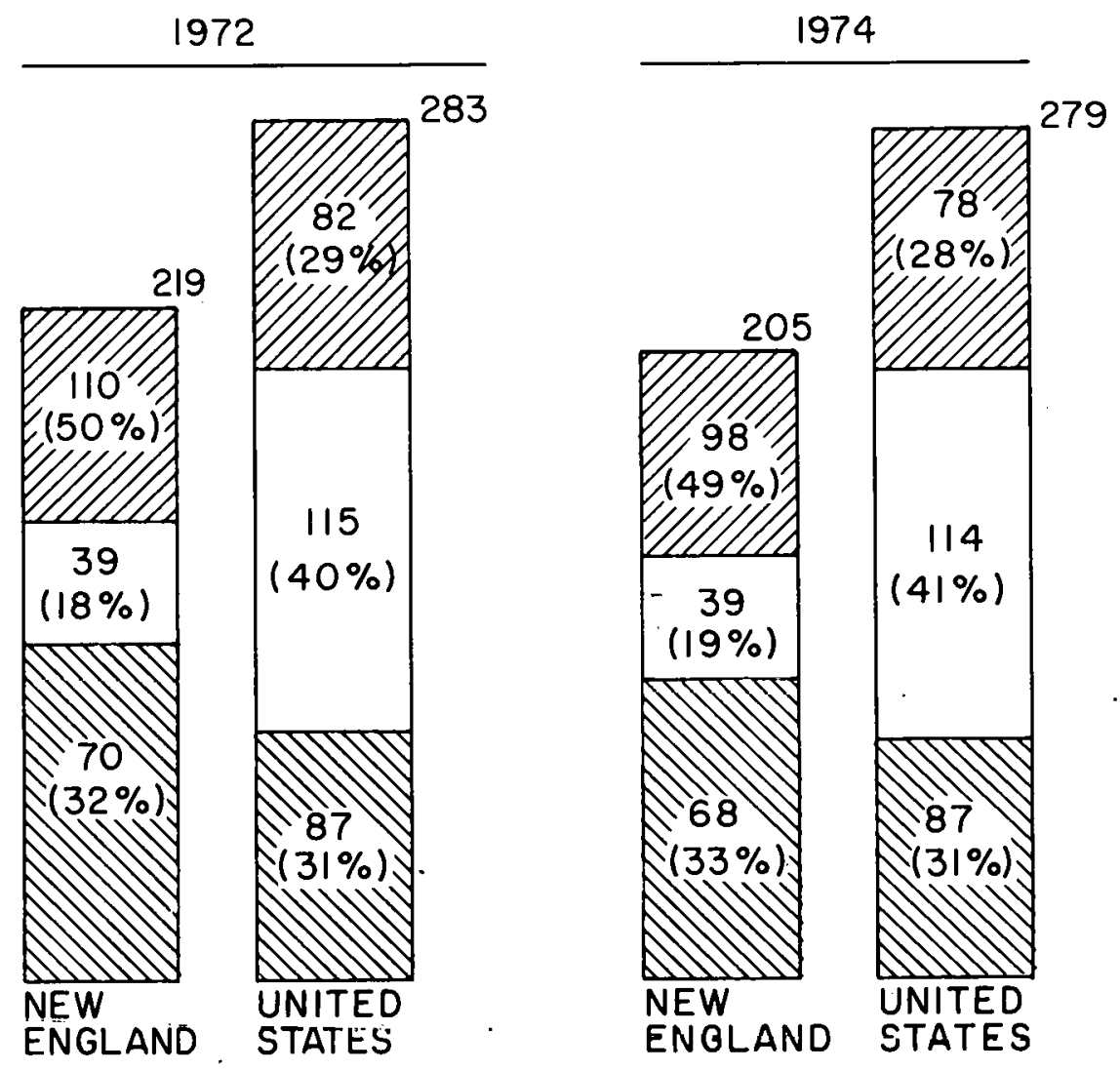

RZA RESIDENTIAL \& COMMERCIAL

$\square$ INDUSTRIAL

$\square$ TRANSPORTATION 
the industrial sector. While this is partly due to the particular industrial activities engaged in in New England and the fact that industries in New England have had strong economic incentives to use energy efficiently for some time, it also reflects the fact that New England imports many goods that were manufactured, in some cases in energy intensive industries, in other regions of the country. Thus, New England effectively imports a substantial amount of energy in the form of manufactured products.

\section{The Effect of Energy Conservation}

Figure 2 also reveals that New England reduced its per capita consumption of energy more than the nation as a whole both in absolute and percentage terms between 1972 and 1974 . It is sometimes suggested that the reduction observed in New England resulted from the fact that a much larger portion of total energy consumption occurs in the residential and commercial sector in New England than for the United States as a whole and that this sector has historically been more responsive to changes in energy prices. However, it should also be noted that within the residential and commercial sector, New England reduced its per capita energy consumption more than the United states in both absolute and percentage terms. Thus, even if New England had had the same distribution of energy consumption over sectors as the United States, we wnild still have sccn a larger reduction in per capita energy consumption in New England than in the United States. When interpreting the data on residential and commercial energy consumption in New England, it should be remembered that part of the reduction in per capita energy consumption observed between $19 \% 2$ and 1974 was due to the winter being milder in 1974 than 1972 .

Figure 2 indicates that energy consumption for both New England and the United states remained essentially unchanged between 1972 and 1974 on a per capita basis in the industrial sector. However, New England cut back about 3\% on per capita energy consumed in the transportation sector while there was essentially no reduction in transportation energy use in the United states as a whole. 


\section{Energy Supply}

In 1975 New England imported over 98\% of its major energy resources either from other regions of the United states or from foreign countries. In addition to its dependence on energy supplies from outside the region, New England has come to rely much more heavily on petroleum as a source of energy, particularly foreign imports, than the rest of the country.

Figure 3 shows the mix of energy sources and imported fractions for New England and the United states. Figure 4 presents the fuel mix for New England and the United States in greater detail for a period preceding and following the oil embargo. It is clear from Figure 3 that while New England differs somewhat from the United States in terms of the percentage of energy obtained from nuclear and $\mathrm{l}_{i_{i}}$ droelectric plants, the major differences are (1) that the United states on the average meets a large portion of its energy demand with natural gas and coal, while New England relies much more heavily on petroleum, and (2) that New England relies on foreign imports for a much larger portion of its petrolcum products than the United states.

Approximately 80\% of the energy use in New England in 1974 came from petroleum, whereas the corresponding percentage for the United States as a whole was about half that: $42 \%$. Of the petroleum products used in New England, about $34 \%$ were direct foreign imports. However, since most of the petroleum products consumed in New England are purchased from domestic sources and refined from foreign crude, New England is actually dependent on forcign sources for over $80 \%$ of the petroleum products used in the region. 
Figure 3.

COMPARISON OF NEW ENGLAND AND U.S. ENERGY RESOURCES, 1974

NEW ENGLAND

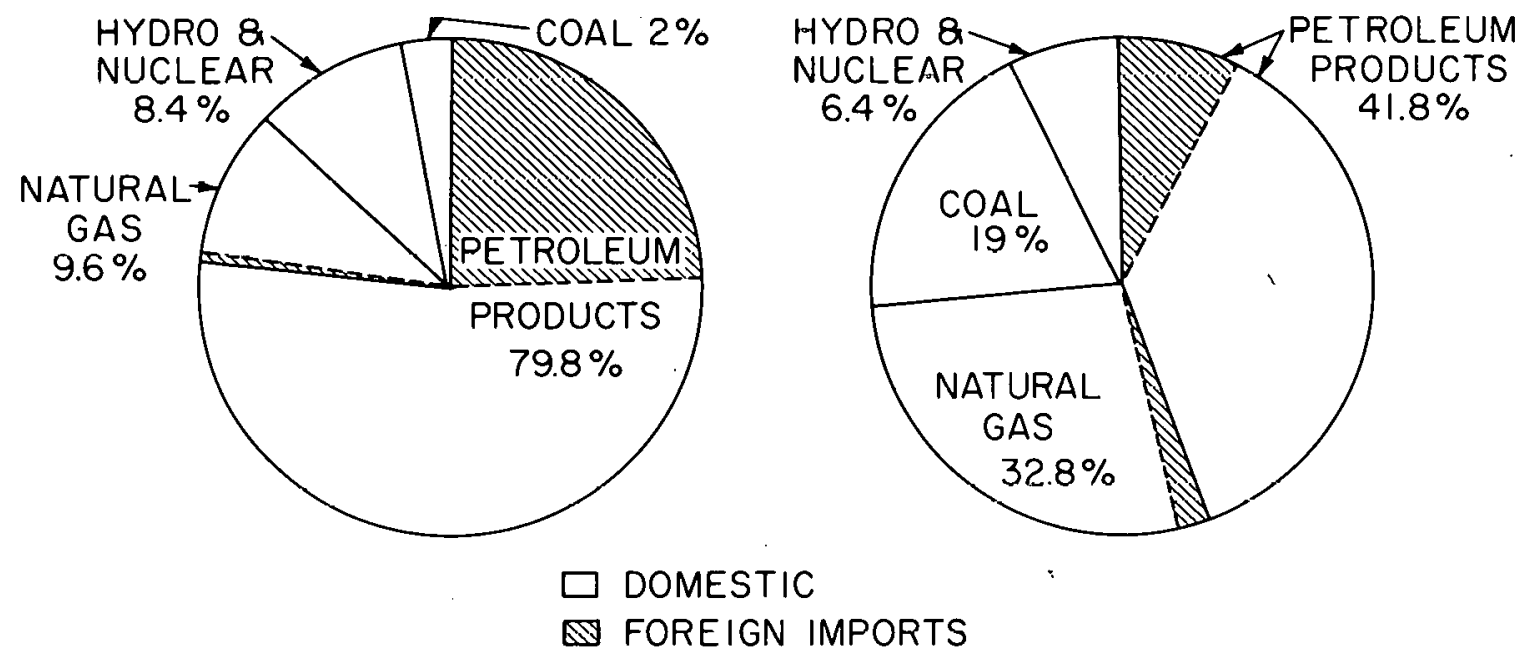

U.S. 
Figure 4 .

COMPARISON OF NEW ENGLAND AND U.S ENERGY USAGE

$\underline{1968}$

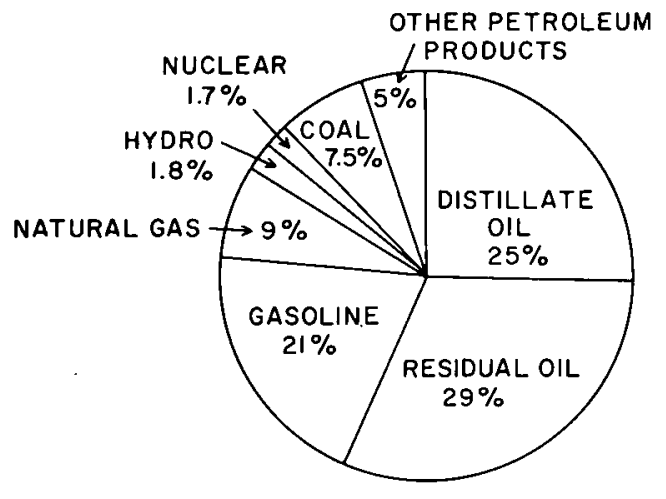

NEW ENGLAND

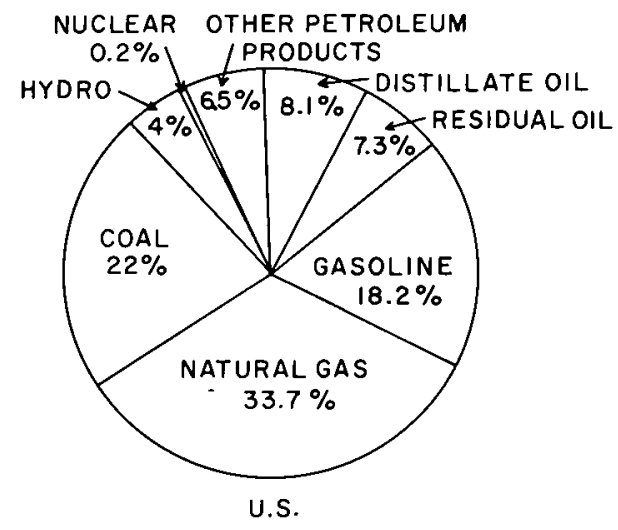

1974
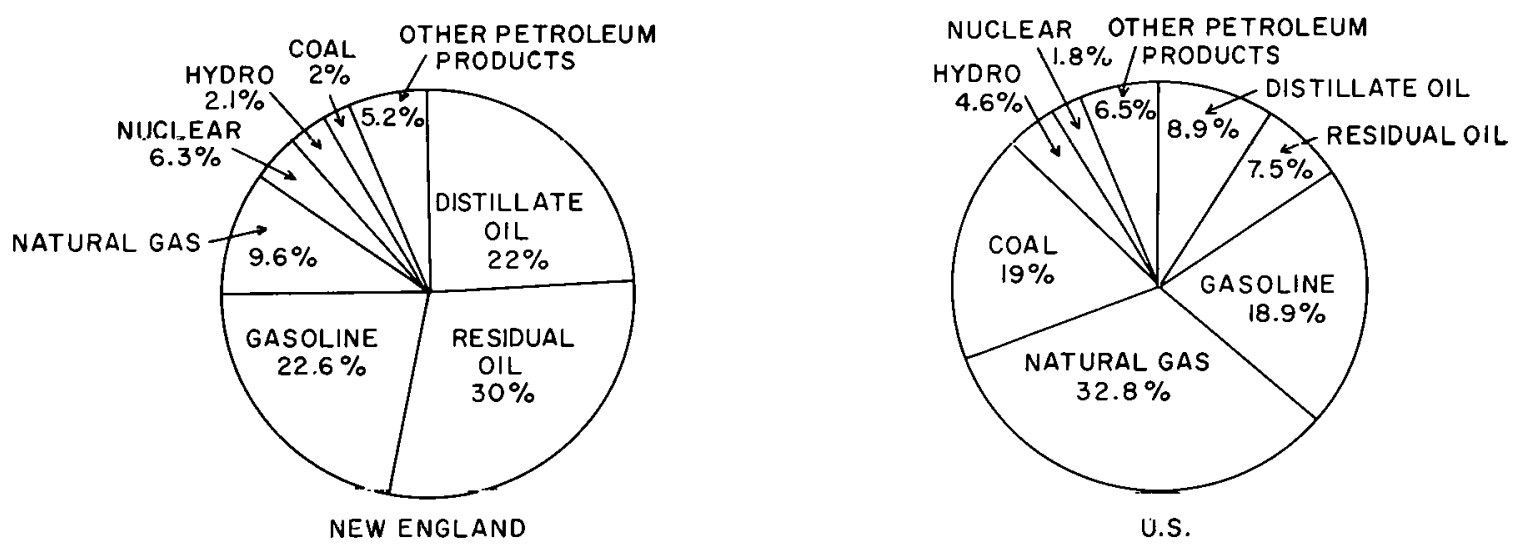

Source: "Son of Strawman" data, FEA, April 1976. 
Figure 4 indicates that the mix of resources used for energy in New England and the United States has not changed substantially over the last 6 years. The most noticeable change, particularly for New England has been the increased use of nuclear power in 1974 as compared to 1968 .

A closer look at the fuel sources for electric generation is presented in Figure 5. It is evident that New England has shifted to heavy reliance on nuclear and oil fired plants while the United States depends much more on coal fired plants. Preliminary data indicate that approximately $29 \%$ of the electric power produced in New England in 1975 was generated in nuclear power plants. Some recent projections suggest that most growth in capacity in New England will result from the installation of nuclear power plants and that by 1985 they will account for over $30 \%$ of the installed capacity in the region and will provide over $40 \%$ of the electric power generated. The reserve margin is expected to fall until the early 1980's to approximately 19\% as the current system matures. However, as large new nuclear units come on line, the reserve margin will rise and is expected to be about 23\% by the mid 1980's.

Figures 6, 7, and 8 show the sources and distribution of petroleum products and natural gas used in New England.

D. Trends and Projections of the Demand for Energy

Figure 9 shows the historical trends of energy consumption in New England along with some recent projections of possible energy consumption levels in 1985. The historical data indicate that energy consumption grew in New England at an average annual rate of about $3.6 \%$ per year from 1968 to 1973. A noticeable drop occurred during and after the oil embargo of 1973 such that 
Figure 5.

ELECTRIC GENERATION FUEL SOURCES

1974
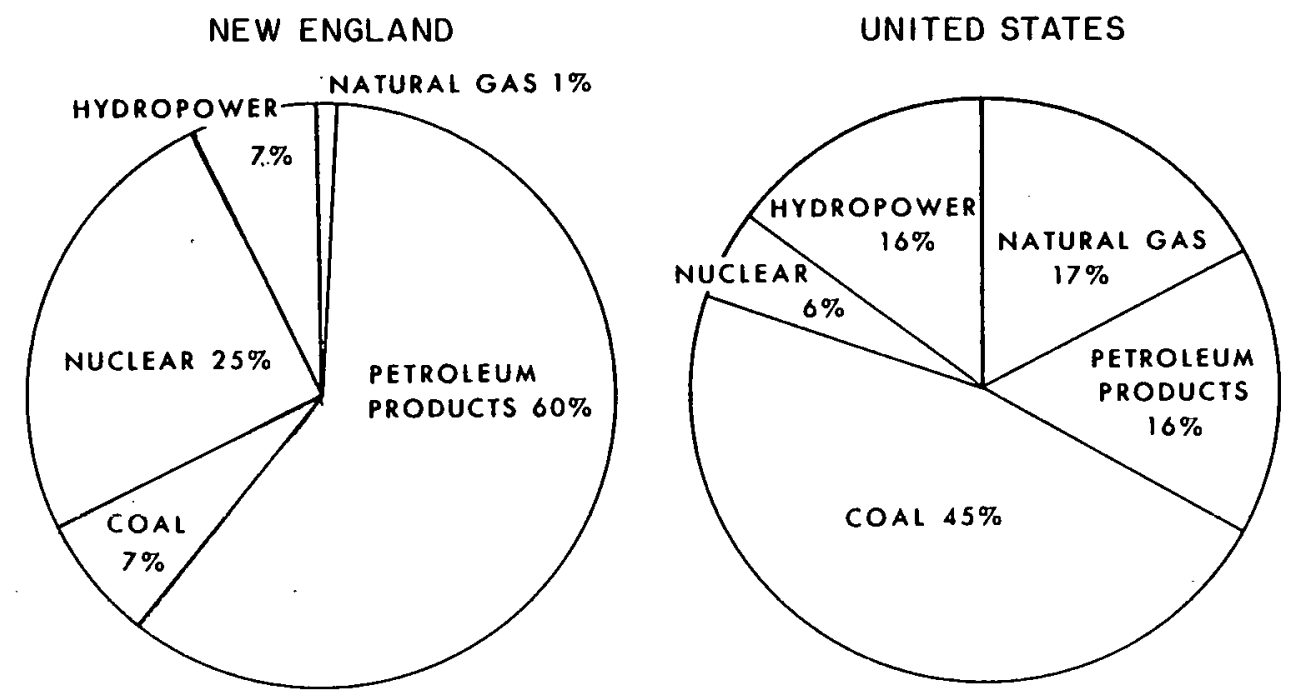

Source: "New England Hydroelectric Development Potential," Hydroelectric Facilities Workgroup, Energy Resource Development Task Force, New England Federal Regional Council, June 1976. 


\section{Figure 6}

SOURCES OF NEW ENGLAND

REFINED PETROLEUM PRODUCTS

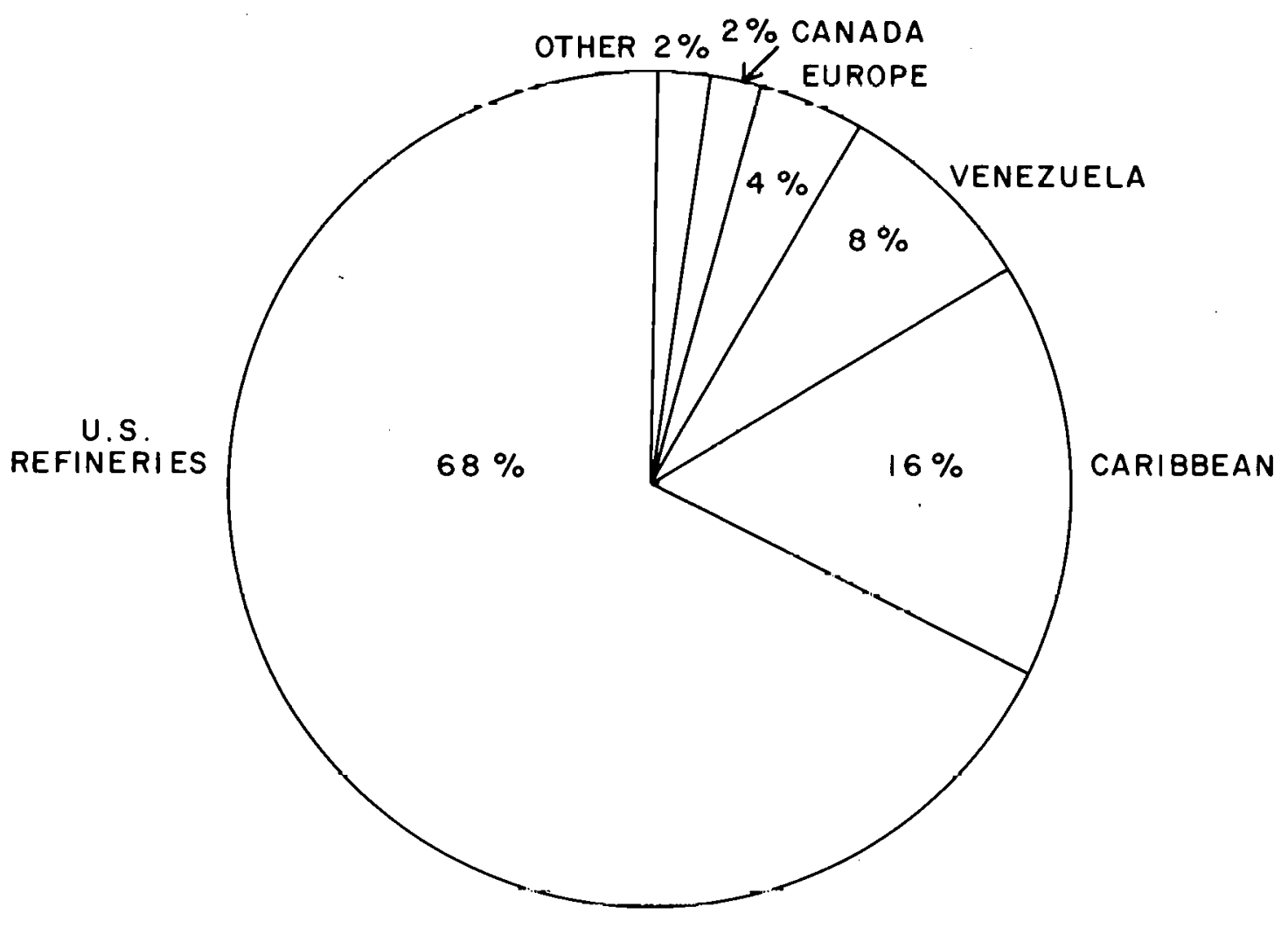

SOURCE: "NEW ENGLAND ENERGY POSTURE BACKGROUND AND 1985 ALTERNATIVES", FEA REGION I, SEPTEMBER 1976. 


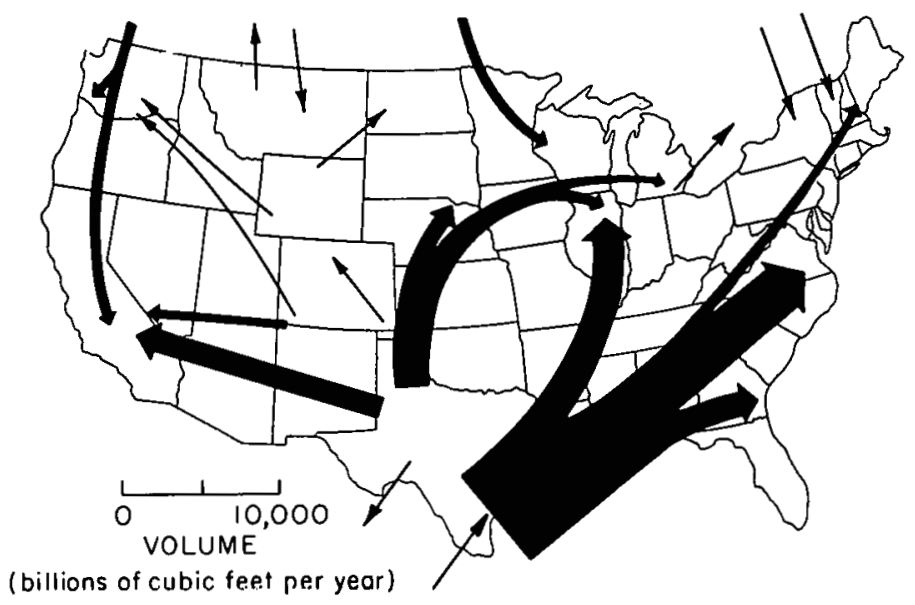

Figure 7: Interstate Natural Gas Movements, 1970.

Source: Gasfacts, American Gas Association, Arlington, Va., 1973.

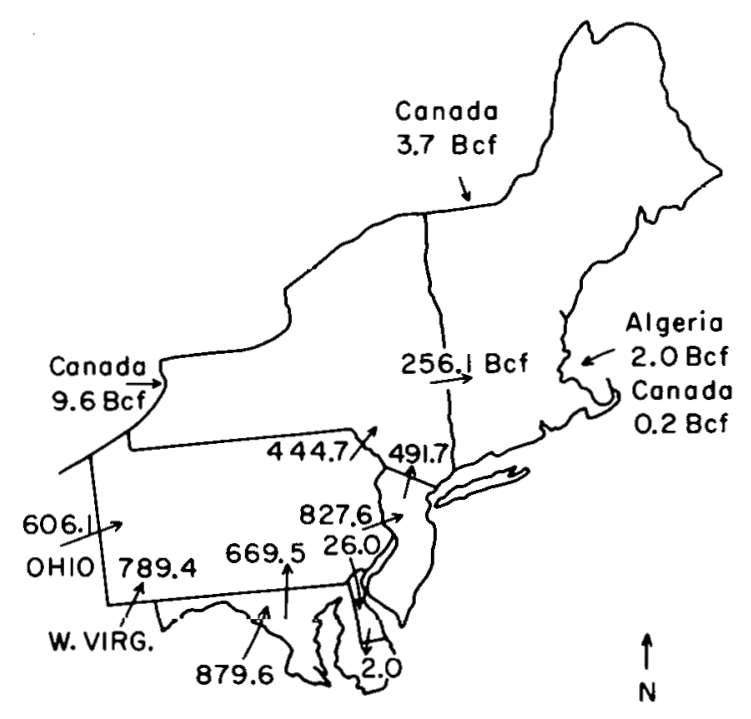

Figure 8: Gas Flows to the Northeast, 1973.

Source: Minerals Yearbook, U.S. Bureau of Mines, various years. 
Figure 9.

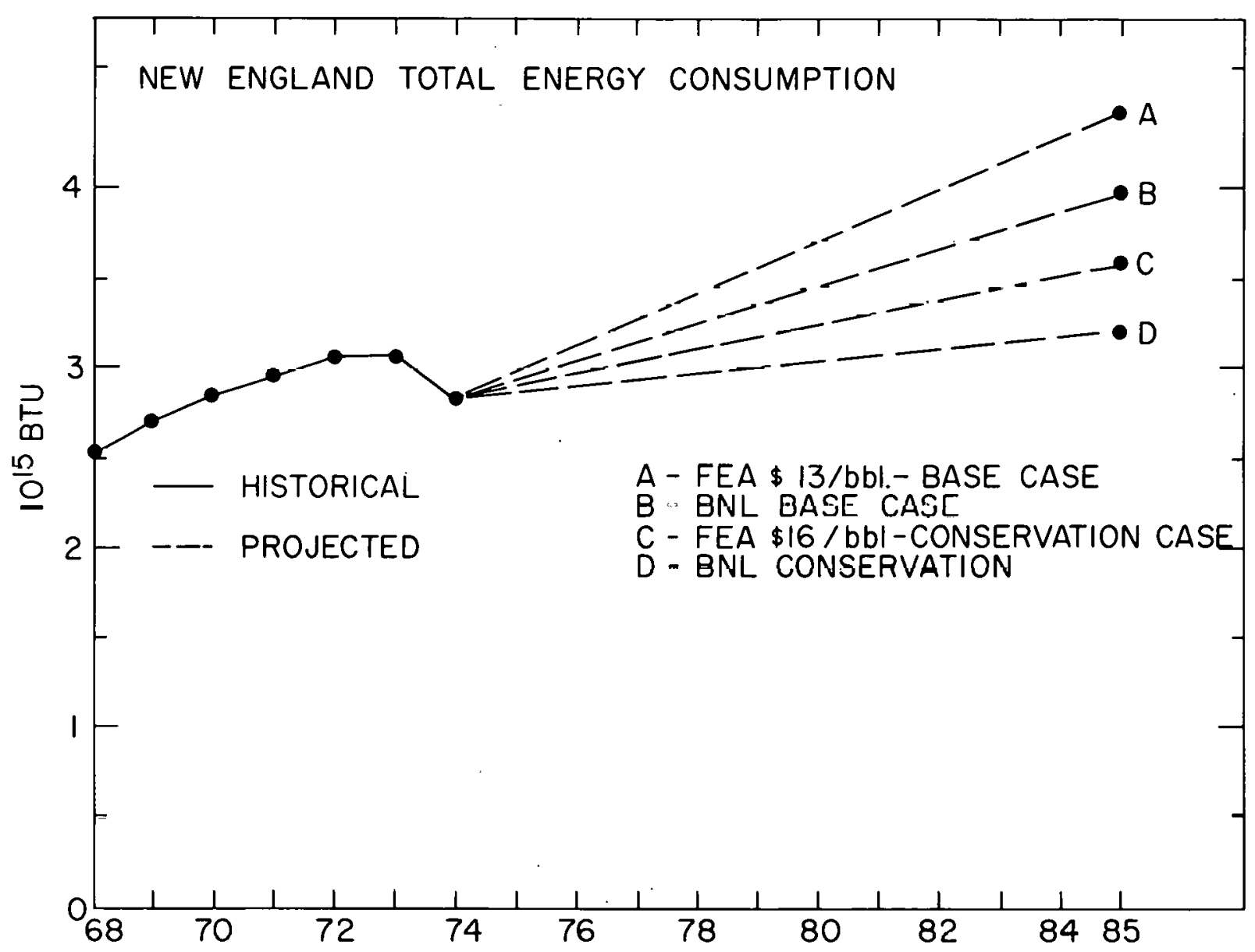

Sources: "Son of Strawman Data", FEA April 1976; "Interim Report to the New England Energy Policy Task Force", FEA Region I, June 1976; and "A Perspective on the Energy Future of the Northeast United States", Brookhaven National Laboratory, BNL-50550, June 1976 . 
the level of energy consumption in 1975 was slightly less than it was in 1970 .

Four projections are shown in Figure 6 for total energy consumption. The wide range of possible levels of energy consumption in 1985 shown by these projections is indicative of the wide range of possibilities open to federal, state, and local governments to affect the efficiency, patterns, and levels of energy use in New England.

Figure 7 shows the historical trends and some recent FEA projections for certain selected energy forms: gasoline, heating oil, and electricity. Federally mandated improyements in automobile fuel efficiencies are expected to result in the nearly constant level of gasoline consumption shown in Figure 7 even though automobile usage is expected to increase over time.

Although the consumption of electricity grew at about $8 \%$ per year from 1964 to 1973, this growth occurred primarily in the residential sector. The shift in relative importance of consuming sectors can be seen in Table 4 .

$$
\text { Table } 4
$$$$
\text { CONSUMPTION OF ELECTRICITY 1964-1973 }
$$

\begin{tabular}{lccc} 
Sector & Growth $\left(10^{9} \mathrm{Kwh}\right)$ & & Growth Rate Per Year \\
\cline { 2 - 3 } Residential & 14 & $9 \%$ \\
Commercial & 11.8 & $11 \%$ \\
Industrial & 8 & $5.4 \%$
\end{tabular}

\section{E. Energy Prices}

on the average in 1974, New Englanders paid 38\% more for their energy than those living in ollies pal ls of the cuuntry. This difference has been increasing over the years. In 1970, for example, the difference was about 30\%. There are basically two reasons for 
Figure 10.

CONSUMPTION OF ELECTRICITY AND SELECTED PETROLEUM PRODUCTS

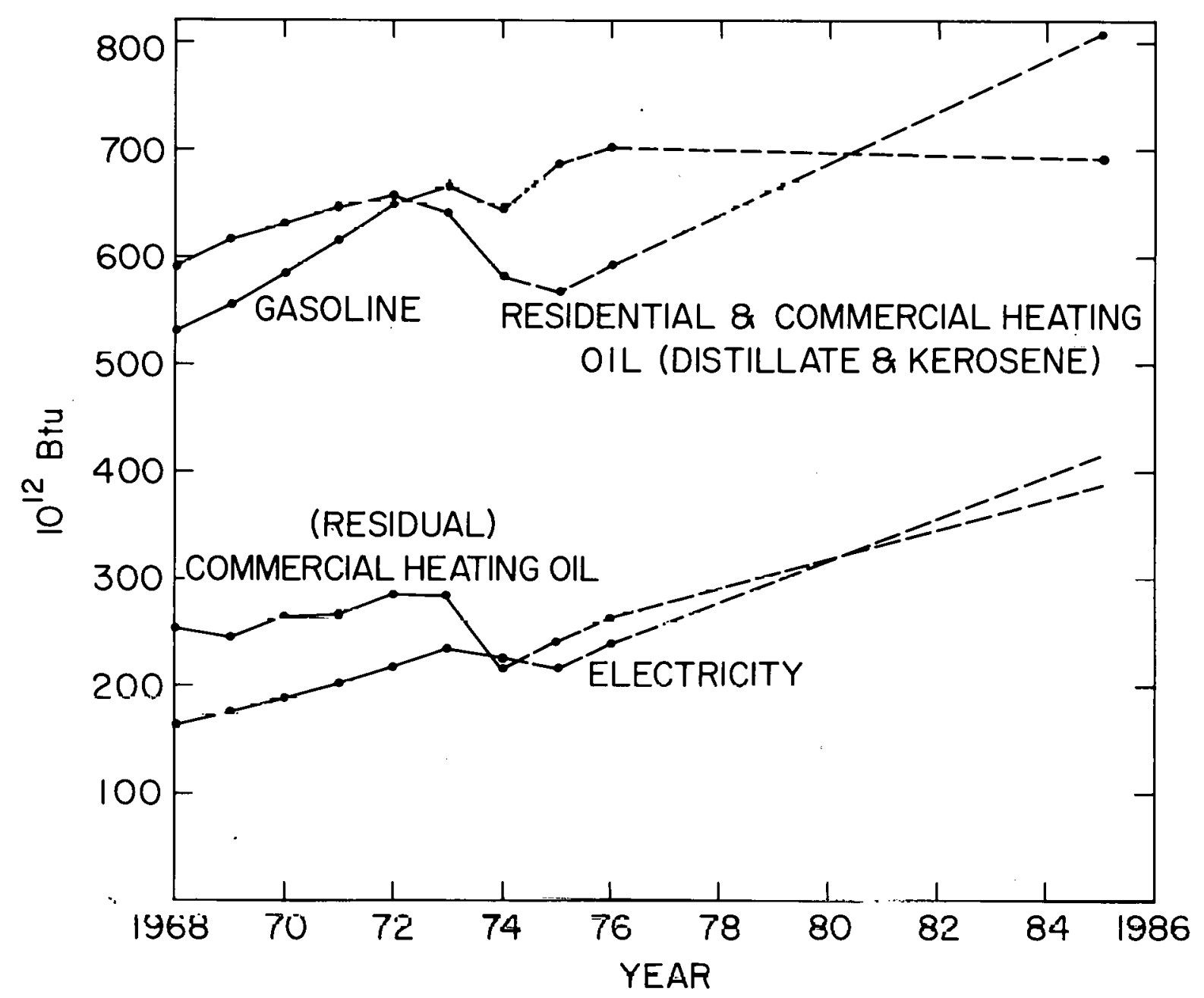

Source: "Interim Repurt to the New England Energy Policy Task Foree," FEA Region I, June 1976, and "Son of Strawman" data, FEA, April 1976. 
this situation: the higher prices paid for individual fuels in the region, and the specific mix of fuels used.

Table 5 compares average prices for certain fuels in New England with the national average. Natural gas and coal show large price differences primarily due to geographical relationships and costs of fuel transport. The high cost of electricity in the region is due partially to the high cost of petroleum, which is used to generate approximately $60 \%$ of the electricity in the region. Not only are the fuels used in New England relatively expensive, but from 1971 to 1974 the rise in fuel prices had a much larger impact on New England than on the nation as a whole. Figure 11 shows the cost components for several fuels.

The individual prices of fuels account for only a part of the differential in energy costs in the region. Also important is the quite different mix of fuels used in the region, as shown in Figure 3. This can be seen by the fact that, based on 1974 prices, if the region purchased its fuels at average U.S. prices, the average fuel bill would be $11 \%$ higher in New England than in the U.S. as a whole. Petroleum is a relatively expensive energy resource, and it is New England's heavy reliance on petroleum that is responsible for this portion of the high overall fuel cost in the region.

However, one should not conclude that because the region's mix of fuels can account for only an $11 \%$ energy cost differential that it is therefore simply regional price differences, and not - differences in fuel mix, which account for most of the higher.cost of energy in New England. The high cost of electricity alone accounts for over $40 \%$ of the energy cost differential. But, as we have seen, electric generation is much more heavily dependent on petroleum in New England than in other regions of the country. Thus, once again, the region's heavy dependence on petroleum is seen as a major factor contributing to its high energy bill. 
$\$ /$ MIL. BTU

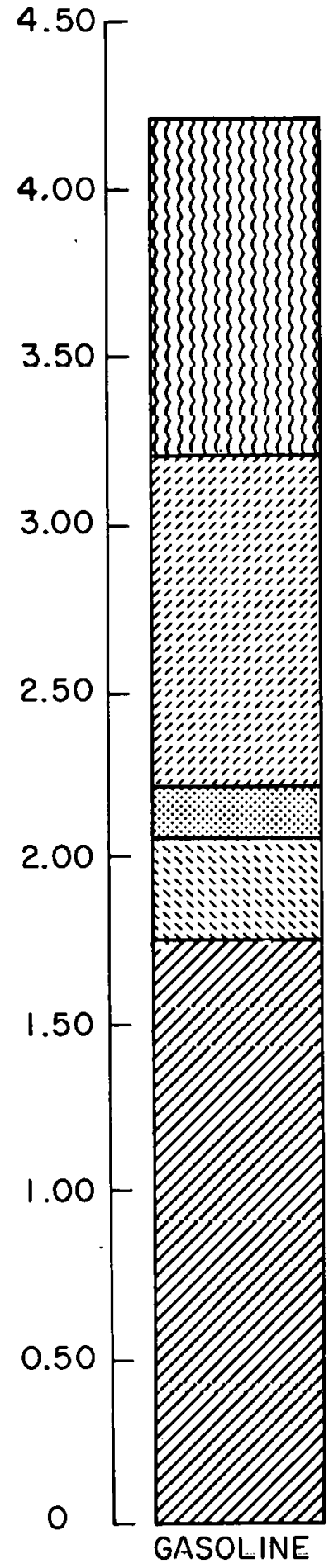

Figure 11 .

NEW ENGLAND ENERGY COST COMPONENTS

END OF 1974

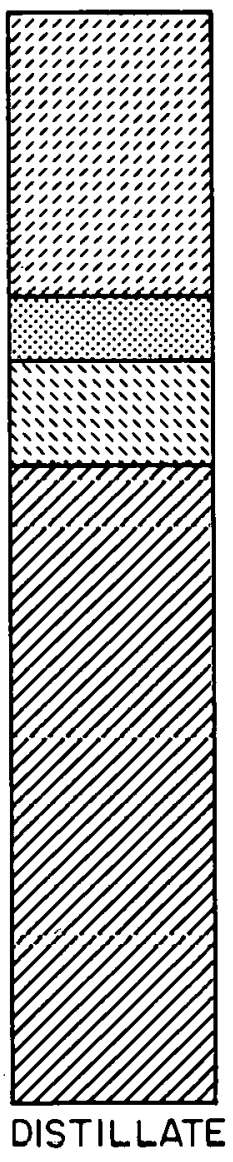

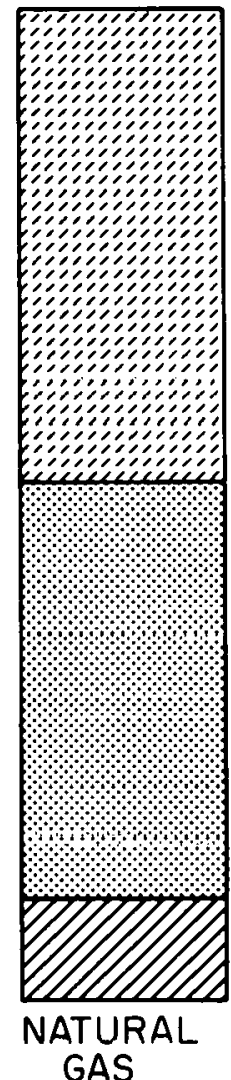

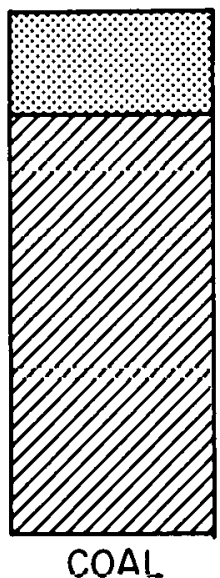

Source: Linda K. Mansfield, "The Price Differential for Energy Between New England and the United States - Updated," FEA Region I, Boston, Mass., May 30, 1975. 
Table 5

Comparison of Average Prices for Selected Energy Products

- New England and U. S.

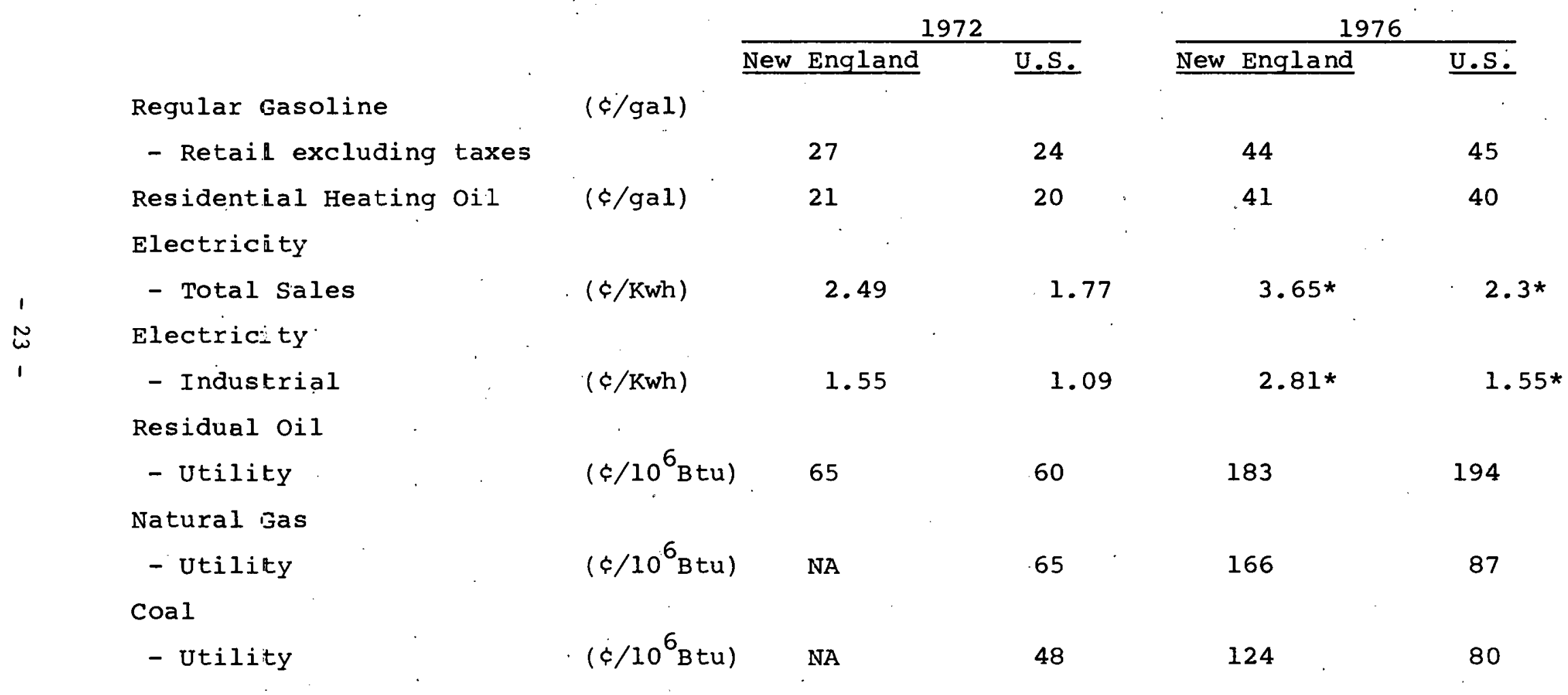

*Prices are for 1974 
The next most important factor contributing to expensive energy in New England, after the high cost of electricity and the heavy reliance on petroleum, is the price of natural gas in the region. The high price paid for natural gas can, by itself, account for over $17 \%$ of the energy price differential between the New England and national averages.

While it is apparent that both fuel mix and fuel specific regional price differences are responsible for the high cost of energy in New England, it is not at all certain how changes in these factors would affect the relative cost of energy in the region. For example, recent changes in coal prices and likely regional price differences for this resource are such that a major shift to coal by utilities, as a substitute for residual oil, might not bring about any reduction in electricity prices. Deregulation of natural gas, while it would most certainly raise gas prices in New England, might have a much more severe impact on other regions of the country. This is because the rest of the nation meets a much larger portion of its energy demand with natural gas, as seen in Figure 3, and because deregulation may have a greater impact on gas prices in some other regions. It may well be, as stated by the Massachusetts Energy Policy Office, that deregulation would adversely affect other regions far more than New England and that, in particular, deregulation could enhance the competitive position of industry in the New England region.

F. Energy Sources Indigenous to the Region

Less than $2 \%$ of New Enqland's qross enerqy consumption is currently supplied from hydroelectric plants. Essentially all other commercial energy sources used in the region are imported from other domestic or foreign sources. Various estimates have been made of the amounts of energy which could be supplied by 
conversion of some of the energy found in solid waste, wood, sunlight, and wind. While recent FEA estimates are that such sources will provide less than 1\% of the region's energy by 1985, other more optimistic estimates are more than double this.

There is also some possibility of increasing the supply of hydropower in the region. A recent report on "New England's Hydroelectric Development Potential" states that approximately 3.2 billion Kwh could be attained by developing hydropower sites that have benefit to cost ratios greater than 0.8 . In addition, this report estimates that close to 1.9 billion Kwh could be obtained from tidal power. Since the actual benefit to cost ratio of many of these sites is less than 1 , these numbers suggest that hydro and tidal power facilities would at most supply less than 3\% of the region's gross energy demand as projected by the FEA for 1985 .

The role indigenous energy sources could play in meeting New England's energy demand is discussed further in section III, "Regional Energy Issues."

\section{G. Environmental Issues}

Water Resources

Lack of adequate water supplies to meet expected demands is an increasingly serious problem in the Northeast. Representatives from the New England River Basins Commission (NERBC), state and federal environmental and planning agencies, regional planning commissions, as well as other government units, have all identified shortages of both surface and groundwater as important constraints to future growth in the area. Also identified as problems are fluctuations in flow due to impoundments used for hydroelectric power generation, frequent major flooding, and depletion of groundwater supplies due to increased pumping. Interestingly, despite severe conditions imposed during New England droughts of the 1950's and 1960's, no new major water supply programs such as reservoirs or aquifer recharge projects have been 
undertaken. However, there is a controversial proposal for augmenting Boston's water supply by transbasin diversion of Connecticut flood waters using the Northfield pumped storage facility. Most of the storage of the Connecticut, Housatonic, and Merrimack Rivers has already been utilized, though storage of the Androscoggin River (New Hampshire), as well as the Penobscot, Kenebec, and St. John Rivers (Maine) remain undeveloped.

Widespread concern also exists for the quality of the region's water. Agricultural runoff, discharqes from industries (primarily textiles, pulp and paper, tanneries, silviculture, and refineries), municipal sewage treatment plants, and malfunctioning private septic systems have all been identified as major sources of pollution. Approximately $50 \%$ of New England's main stem river and tributary mileage presently do not meet the fishable-swimmable water quality standards stipulated by the Federal water Pollution Control Act (PL92-500). While conditions with respect to this goal continue to improve, it is doubtful that the target date of 1983 for the standards will be met by the region. Dissolved oxygen and bacterial levels are the most frequently violated water quality criteria. Chloroform, $\mathrm{PCB}$ 's and lead are presently focal points for specific water quality improvement programs. In a five-year study (1962-1967) of U.S. rivers and lakes, the Federal Water Pollution Control Administration identified 19 trace metals in the waters of the Northeast. Zinc, boron, iron, manganese, aluminum, copper, lead, chromium, barium, and strontium were all observed in the study with a frequency of at least $36 \%$, although basin averages for these metals were generally found to be equal to or below nationwide averages. While some specific elements such as copper and zinc in trace amounts are actually beneficial to health, the presence of the indicated metals is usually taken as representative of degraded water quality. 
Restoration to the area of anadromous fish (e.g., salmon) has been hampered due to lack of or poor facilities for fish passage through existing impoundments especially at older run-of-river hydroelectric plants on the connecticut and other major rivers. Concern also exists for fishing and recreational activities in the coastal zone, primarily because of proposals for deep water ports, tank farms, refineries, tanker traffic, and drilling platforms, all related to offshore oil activities. Pollution from oil spills is already a problem in western Long Island sound (as is the problem of nutrient enrichment), in Boston Harbor as well as Lake Champlain and the Champlain Barge Canal. Thermal effluents from existing and proposed nuclear and conventional power plants have already been identified as a potential water related problem; the imposition of cooling towers on all new thermal plants, while largely removing thermal capacity constraints, creates consumptive water use problems.

Institutional and legal constraints will be increasingly important in relation to water resource use in New England. Meeting demands for both water quantity and quality by competing users will require an interconnected system of cooperating agencies to implement much needed programs for increased water storage, flood management, and interbasin transfers.

\section{Air Quality}

The New England states have had faix success in controlling pollution from stationary fossil fuel combustion. Of 1240 major polluters identified in New England as of 31 December 1975, 946 (76\%) were in compliance with emission standards or on schedule toward compliance and 244 (30\%) were in violation (the status of 50 (4\%) was unknown). There were no violations of the $\mathrm{SO}_{2}$ ambient air standard in either 1974 or 1975. Particulates remain somewhat 
of a problem. The ambient standards were violated at at least one monitoring station in every state but Maine. Nitrogen oxides, a product of both stationary combustion and automobiles, was satisfactory at all stations but two (and those two only slightly exceeded the standard).

Relaxation of emission standards and/or shifts from oil to coal at electric power plants could alter this situation. Some evidence has been presented that selected conversion to coal, with appropriate environmental safeguards, could be made without violating $\mathrm{SO}_{2}$ standards. The large population at risk in the Northeast certainly requires that caution be exercised in such a decision.

The same success that was achieved with respect to $\mathrm{SO}_{2}$ has not been achieved with automobile pollutants. In 1975, carbon monoxide standards were violated at most monitoring stations (21 of 31 ) and oxidant standards were violated at essentially all stations.

As would be expected, New England's air is generally cleanest in the rural areas and more polluted in heavily developed urban and suburban regions. The dirtiest areas by pollutant in 1975 were

Particulates: Meriden, Connecticut and Worcester, Massachusetts

$\mathrm{CO}$ : New Britain, Connecticut; worchester, Massachusetts; and Providence, Rhode Island

Oxidant: Middletown, New Haven, and Bridgeport, Connecticut.

There is substantial evidence that New England's air is affected by pollutants produced in other parts of the country. oxidant concentrations in Connecticut seem clearly related to auto emissions in the New York metropolitan area. Policy decisions on the use of tall stacks on power plants in Ohio and Pennsylvania may affect sulfate levels in New England. 


\section{REGIONAL ENERGY ISSUES}

\section{A. Introduction}

New Englanders are known for the independence of their views on all matters and under all conditions. Unanimity of opinion on energy matters is precluded--almost on principle--and consensus on specific issues is elusive, transitory and subject to considerable intraregional diversity. And yet the energy conditions of the region have imposed circumstances leading to a convergence of opinion and action that differentiates New England from other regions of the nation.

In this section we attempt to reflect those tendencies and views on energy matters that seem to be most widely held in the region or have resulted in policy or development conflicts. It should be regarded as a sampler of issues, views, and problems rather than as a definitive accounting of opinion. The general caution expressed in the introduction is particularly pertinent here. This review of issues was completed at the end of October, 1976. The rate of transition of energy issues and concerns will make much of this discussion obsolete relatively soon after that date.

These observations have been assembled through personal interviews carried out in the course of the BNL Regional Energy Studies Program, and particularly for this document; participation in state and regional conferences; analysis of regional research activities; and review of periodicals. Some issues and policies are well documented: an example of such documentation is the "New England Enerqy Policy" by the New England Regional Commission reproduced in Appendix A. Others must be inferred from patterns of action or inaction; such as the conflicting regional response to Massachusetts' flat rate referendum.

\section{B. Encrgy Policy}

nevelopment of energy policy is cxtrcmcly complicated. As the use of energy affects all facets of the human and natural environment, all must be considered in developing energy policy. Similarly, 
policies developed at the federal, state or local level affect all other levels of government, the economic community, the environment, and individuals in distinct and diverse ways. It is the successful resolution of diverse concerns (for example resource constraints, technical limitations, environmental quality, health, economic feasibility and consumer protection) which determines the acceptability of general policies.

The absence of a generally accepted federal energy policy is held, by both state governments and private interests, partially responsible for limited regional energy development. Without effective federal initiative the region may not he ahle to attract the investment necessary to diversify and strengthen its energy mix, bolster its sagging economy, protect and improve its environment, and provide the necessary services to its citizens. Failure to establish a federal energy policy exacerbates existing conflicts between federal agencies and between state and federal agencies. While a formal study of the results of interagency policy conflict in the region has not been done indications suggest the results are inefficient problem solving; increased costs; a suboptimal allocation of resources, and the entrenchment of special and unilateral interests. Indeed, an important factor in establishing the regional commissions, the Federal Regional Council Energy Policy Task Force, and the New England Energy Policy Council, Inc. has been the need for improving coordination in policy development and program implementation.

An additional factor in calling for a federal energy policy is increasing recognition that state and federal priorities often differ. Where such policies are inconsistent they nay be aliglled Lhrough arbitration or adjudication, as was the case when the Federal Energy Administration (in 1971) accepted the argument. of New England representatives that the substantially greater impact on those regions dependent on imported oil is inconsistent with the Emergency Petroleum Allocation Act of 1973 and adopted an entitlement system for price controlled domestic oil. More recently the Department of Interior has implemented an Outer Continental shelf petroleum leasing program which several of the states opposed in court (United States $v$. Maine 
No. 35, Orig. - U.S: Mar. 17, $1975-)$. Judicial defeat of the State's case has resulted in a realignment of state programs to meet impending development.

As has been indicated by NERCOM's energy policy statement (Appendix A) and, more recently, several state and federal reports, the region is committed to development of a more nearly balanced energy mix; to reduce dependence on imported petroleum; and to reduce regional inequities in price. Specific policies which the states' choose to follow will be strongly influenced by the extent to which such actions will improve the region's stagnating economy. Unemployment in the region fluctuates 1 to 2 percent above the national average. From 1973 to 1975 farm income in the region fell by over $\$ 110,000,000.00$, contract construction income fell by over $\$ 380,000,000.00$, while federal income (both civilian and military) in the region increased by approximately $\$ 100,000,000.00$ federal income in Rhode Island declined by $\$ 115,000,000.00$. Such losses influence the development of energy policy.

\section{c. Fossil Fuels}

\section{Petroleum}

The dominant use of oil (80\% of the region's total energy needs; high levels of imported oil; and location at the end of the "pipeline" make the region doubly insecure to shifts in petroleum policy. Decreases in petroleum availability will affect both supply and price, increases in price will have a greater marginal impact because of proportionally higher prices existing in the region. Whether the emphasis is placed on high priced oil, or insecure sources of oil, or both, the result is the same: each state would like to move away from petroleum dependence.

\section{Natural Gas}

As with petroleum the essential problem is a declining supply at an increasing price. It is difficult to guage the impact of "firmcontract" gas curtailments on the region (last winter was exceptionally mild). However, the proportionally higher price the region pays for natural gas (and whatever "natural level" the price of "new" gas rises to under altered Federal Power Commission regulations) may have a substantial negative impact on attracting new industry. At least one 
report (from New Hampshire) has also indicated that failure to secure new natural gas contracts has resulted in the loss of new industry for the state.

\section{Outer Continental Shelf Development}

State response to the development of ocs areas has changed following the United States $v$. Maine decision. Prior to the decision states' interests included a share of the leasing bonus, a share of derived royalties, adequate environmental protection, and adequate research to ensure that development proceeds in a beneficial manner. Current concerns include suqqested deficiencies in the environmental impact statement, failure to consider the need for onshore support facilities, and the need for improved rapport with the Department of Commerce Coastal zone Management Program.

Despite such concerns the states recognize that oil or gas finds on George's Bank, and made available to the region, may affect a relative decrease in the cost of energy to the region. An additional factor for support will be the substantial economic benefit on those areas in which onshore facilities are located.

\section{Refineries}

While the history of refinery development in New England is not encouraging the current situation is such that several individuals expressed personal belief that specific states are ripe for development and that failure to site a refinery in the region over the next decade would be the result of poor planning and groundwork, not governmental opposition at the state or local level.

All coastal states have potential refinery and ocs support facility sites. While most states have expressed their willingness (indeed several are actively seeking) to serve as support centers (see for example "Än Analysis of Potential Petroleum Development in Massachusetts," July 1975 prepared by the Massachusetts Energy Policy Office) the same is only marginally true for refineries. Refinery proposals generated for Durham, N.H. and Machiasport, Me., initially supported by state and local governments, ultimately failed to receive the permits necessary to begin construction. The sole active 
refinery proposal at the moment is for Eastport, Me., made by the Pittston Company. The Environmental Protection Agency has announced that hearings on the preliminary environmental impact statement will be held in Eastport, Me. in December of this year.

Other states are actively considering, if not advocating, refinery development. Serious discussions between Venezuelen and Massachusetts interests concerning a Bay state refinery project have been initiated but as of May, 1976 had not progressed to a site specific level. The general public acceptability of a refinery in Massachusetts was determined to be negative on November 2, 1976 when a non-binding referendum is offered to the voters of the State:

\section{OIL REFINERY AND}

DEEP WATER PORT

Non-binding advisory question. "Shall the General Court enact legislation authorizing the construction of an oil refinery and a deep water port, subject to the approval of those communities directly affected and any reservations that the General Court may prescribe?"

The Legislature has placed this question on the ballot in order to determine whether the people favor or oppose the construction of an oil refinery and deep water port in Massachusetts. The vote on this question deals with the general advisability of such construction and is not a specific proposal for a facility. If a specific proposal is made, it would be subject to approval by the communities directly affected and subject to any restrictions imposed by the Legislature.

\section{Petroleum storage}

The New England Congressional Caucus has protested the exclusion of the Northeast from the Federal Energy Administration's strategic Petroleum Reserye Storage Plan. Of the five Early Storage Reserve sites designated one is in Texas and the remainder are in Louisiana. The Caucus seeks to ensure that, in case of a major interruption of oil supply, the FEA fulfill its mandate to provide for the region's 
needs by assuring product processing and timely delivery from the reserve stocks.

\section{Coal}

Despite utility coal costs twice the national average the Edison Electric Institute reports that coal is the cheapest fossil fuel available for electric generation in the region. Yet regional utility use is about $15 \%$ of the national average, mostly at the Bow, N.H. power station. The potential for increasing coal use will depend on resolution of a series of distinct, though not entirely independent, issues:

First, utilities must be allowed to burn coal; through improvements in the economics of environmental control technologies; through relaxation of environmental standards and regulations; by increasing the availability of high Btu low sulphur coal; through the development of reliable and accepted coal generating plant siting criteria; or by some mixture of the above.

Secondly, for continued expansion of coal use in the region additional problems are confronted; direct burning or gasification technologies should be compatible with existing and potential federal and state regulations; the transportation infrastructure is not adequate to meet potential coal demands; and long term coal contracts are not available.

Coal use issues are complex. The national coal supply is many, many times the size of domestic oil and gas reserves. Early in October Rev. James J. Skehan, a Boston College geologist, announced the discovery of coal veins, bearing semi-anthracite to low-volatile bituminous coal, up to 25 feet thick in the Narragansett Basin. Yet the region cannot buy clean coal and cannot burn cheap coal. Several utilities expressed the opinion that current dependence on oil is partially the result of failure to obtain long term coal supply contracts some six or seven years ago. More recently the Federal Energy Administration (FEA) announced it will not issue a coal conversion order for the Schiller, N.H. generating station until the 
environmental impact statement is drafted and the public and Environmental Protection Agency has had a chance to comment on the adequacy of environmental controls.

The Northeast Rail Services Act (P.L. 93-236, Dec. 11, 1973) and the "Preliminary System Plan" (Feb. 1975) proposed by the U.S. Railway Association affects the ability to transport bulk coal to consumers in New England. While the urtimate fate of the railway system is unclear, abandonment of many miles of light density unprofitable spur lines is explicit. Some state governments are actively supporting spur lines which the Plan would have allowed to collapse. They will continue to support the rail system over other forms of coal transportation which do not provide equal or greater social and economic benefits.

\section{Nuclear}

The major symptom of nuclear malaise in the region appears to be public opposition. The majority of sentiments expressed in the press or at nuclear hearings are vehemently opposed to the construction or operation of nuclear power plants. The New England Governors (with the exception of Meldrim Thomson, Jr., a nuclear advocate) appear, at best, resigned to fission power. The utilities, finding it difficult to burn coal and expensive to burn oil, see no feasible alternative.

The interaction of interested parties (the public, the regulatory agencies, and the utilities) contributes to, enhances, and prolongs the nuclear electric controversy and plant specific licensing procedures. An example of such conflict is currently at issue in Seabrook, N.H. where a proposed nuclear plant has developed into a major regional issue pitting a diverse array of anti-nuclear groups (including the Clamshell Alliance, the Union of Concerned Scientists and the New England Coalition on Nuclear Pollution) against the Public Service Co. of New Hampshire (PSC), the N.E. Council for Economic Development, the New Hampshire state Labor Council (AFL-CIO), and Governor Thomson. 
On August 4, 1976 groundbreaking ceremonies at the proposed site and a luncheon at the Exeter Inn were interrupted by protesters. Six protesters, members of the newly formed Clamshell Alliance, were arrested, found guilty on charges of criminal trespass, given a twentyday suspended sentence, and released on $\$ 100$ personal recognizance. Following on the Nuclear Regulatory Commission's (NRC) decision that new licenses to build or operate nuclear power plants would not be issued until radioactive waste disposal problems were resolved the Atomic Safety and Licensing Appeals Board (ASLB) rescinded PSC's construction permit. At this finding plant opponents rejoiced, plant advocatos called for NRC review and William Tallman, President of PSC, revised the total construction cost of the project from $\$ 1.6$ billion to $\$ 2$ billion. Tallman explained the increase was due to interest payments and inflation. On October 5, NRC reversed the ASLB and allowed construction on the plant to proceed explaining that the problem prompting suspension of the building permit was on its way toward resolution. Response to this finding has been mixed. Both the PSC and Governor Thomson hailed the decision; Governor Thomson citing it as "the best news he has heard since becoming governor" (Concord Monitor, oct. 6, 1976). Opponents of the plant called the decision "shocking and disgusting" and questioned the integrity of the ruling.

Despite the NRC decision to allow the continuation of construction the Seabrook nuclear controversy assumed an added dimension when, on November 9, 1976, the Federal Enviornmental Protection Agency revoked its approval of the plant's cooling system.

Elsewhere in the region, nuclear controversies have not been lacking. The Vermont Yankee plant operating license was remanded to the Atomic Safety and Licensing Board (following an appeals court decision) for determination of whether the liccnsc should be continued modified or suspended. Additionally the state of Vermont brought a court suit against the plant for unauthorized discharges. Connecticut has been concerned with its lack of an effective evacuation plan. 
Governor Noel of Rhode Island has been criticized by nuclear opponents for support of a meteorological tests at the proposed Charleston nuclear site.

E. Solar and Alternative Energy Resources

Energy alternatives attracting regional interest include solar, hydropower, tidal power, solid waste, and biomass. While the potential contribution of these resources is limited, with proper encouragement their use can help offset continued dependence on uncertain oil supplies, can provide for beneficial and improved utilitization of resources, and, can provide varying scales of development suited to the region's range of rural/urban environments.

\section{Waste and Wood}

Waste utilization has gained regional acceptance if only as it offers a potential solution for two problems, disposition of municipal waste and diversification of the energy resource base. The connecticut Resources Recovery Authority is presently selling a 53 million dollar bond issue for a facility to be. located in Bridgeport and work has started on a second facility. The Rhode Island Solid Waste Management Corporation plans to issue a Request For Proposal for the first Rhode Island facility next year. Massachusetts has a program under the Executive office of Environmental Affairs and is negotiating with a private utility to build a facility in Haverhill, Mass. designed to process 3,000 tons per day of waste, serve approximately 50 communities and generate 50 megawatts of electricity.

Wood and agricultural waste have also attracted attention as potential energy or fuel resources. While wood is currently utilized as fuel for process heat and to a marginal extent for home heating and cogeneration, there have been few plans to develop electric generation plants using wood as a fuel (the lone exceptions to this have been Green Mountain Power co. in Vermont and the Maine Wood Fuel Corporation in Bangor, Maine). 


\section{Hydropower and Tidal Power}

There have been a number of major hydro and tidal power projects proposed in the region. At the moment the two largest (in size, in paper work, in press coverage, and controversy) are the Dickey-Lincoln School Lakes hydropower project and the Passamaquoddy tidal power project.

The Dickey-Lincoln School Lakes project was authorized by Congress in 1965 at which time planning was initiated. The project consists of two impoundments: The Dickey Dam site, on the upper St. John River immediately above its confluence with the Allagash river, would be an earth filled structure impounding a reservoir with a gross storage capacity of 7.7 million acre-feet. The project would be operated for peaking purposes and have a total installed capacity of $760,000 \mathrm{~kW}$. The second site, Lincoln School, is eleven miles downstream from Dickey. It is much smaller having a useful storage capacity of about 24,000 acre-feet and would be used for regulating discharges from Dickey Dam and for base load power generation (two $35,000 \mathrm{~kW}$ units are authorized for this site).

There are three Canadian power plants below the Dickey-Lincoln sites whose energy output will increase through improved flow regulation. One half of the Canadian power increase would come back lu tile U.S.

Many Passamaquoddy tidal power studies have been conducted. In the late 1930 's President Roosevelt initiated the first federal feasability study of harnessing Passamaquoddy's tidal potential. In 1955 a joint U.S. - Canadian Commission developed a single pool type project but it fell short economically and was not authorized. The present plan is for a two pool project (the upper pool, in Passamaquoddy Bay, would be mostly in Canada and the lower pool, in Cobscook Bay, in the United States) anticipated to provide primary peaking and some base load capacity.

At the time of the last study in 1974 the benefit/cost ratio was .7 and Congress did not fund. However, in light of current 
oil prices Congress has given the corps authority to review the project for a favorable benefit/cost ratio. If $s$ uch is the case, the Corps anticipates initiating full blown engineering and environmental studies.

In addition to the above projects the Hydroelectric Facilities Workgroup of the Federal Regional Council's Energy Resource Development Task Force has identified 18 other potential hydro sites having a cost/benefit ratio approaching parity, an installed capacity of approximately $1,805 \mathrm{~mW}$, and a total construction cost approaching 1.5 billion dollars.

At least two small hydroelectric initiatives have received setbacks. The City Council of Berlin, N.H. voted to kill a municipal power resolution to appropriate $\$ 60,000.00$ in City money to acquire the Smith hydroelectric plant and local tranmission lines from the Public Service Co. of New Hampshire. Springfield, Vermont, in attempting to apply condemnation proceedings in order to build a dam for a municipal hydroelectric project in a neighboring town (Cavendish) faces a proposed amendment to the eminent domain law which would require the Town of Springfield to pay the legal fees of the Town of Cavendish.

\section{Solar and wind Power}

Both solar power and wind energy systems are seen as attractive potential assets to the regional energy mix. To date no substantive breakthrough of solar or wind systems has occured in the region despite general public and governmental enthusiasm.

A workshop convened in Boston by the Center for Energy Policy, Inc. identified nine barriers to solar commercialization in the region. These include: the high initial cost of solar devices, the lack of impartial--Consumer Report type--technical evaluations of various devices on the market, lack of trained service personnel, necessity of installing conventional back up systeus, absence of site-specific designs--such as building orientation--for conventional construction projects, lack of 
integrated design packages for conventional builders, availability of reliable components carrying guarantees, concern over patent rights if the Federal government sponsors design development, and lack of capital (venture, business and mortgage for purchasers). To these must be added two other barriers; the general lack of legislated incentives for the use of solar energy; and the lack of staff and technical ability in those state agencies deluged with requests for technical advice.

Despite friction to private investment a number of solar initiatives have been made in the region. A New England task force headed by Edward KIng (of the New England Council) has submitted a joint proposal to the Energy Research and Development Administration nominating the Lyman school in Westboro, Mass. as site for the proposed Solar.Energy Research Institute. The Southern Connecticut Gas Company has installed the first of three planned experimental units to test the feasability of solar power as an alternative to gas for space and water heating and the Department of Housing and Urban Development and the Energy Research and Development Administration have funded solar residential demonstration projects in each state in New England.

\section{F. Conservation}

The shock of the oil embargo and high energy costs (combined with fiacal problemo in oeveral etato governments) have led to an artive awareness of the need for energy conservation. This awareness is being translated, with difficulty, into actions designed to reduce the level of energy consuming activities and improve the efficiency of those activities.

Independent of federal support, state governments have been extremely conservation oriented in their own activities. Connecticut, for example, achieved energy cost savings of approximately $\$ 800,000$ in lighting and heating costs for state office buildings over a five month period.

Despite formal conservation policles recent trends indicate that motivation for major conservation efforts in the public sector has 
diminished. To provide enhanced incentives for conservation most states are studying potential voluntary or regulatory programs. These would include; the development of housing codes; insulation standards; interior and exterior lighting standards; alternative electric rate policies; efficiency rating and labeling; automobile weight or engine displacement taxes; toll and municipal parking increases; materials reuse; and, the co-location of industries which can operate symbiotically on a materials or energy basis.

In addition all states in the region have indicated their ability to achieve the energy conservation required to participate in the Federal Energy Administration Conservation Program. The FEA is in the process of awarding grants (ranging from $\$ 50,000$ to $\$ 110,000$ ) for development of state energy conservation plans requiring, but not limited to, the following measures:

- mandatory lighting efficiency standards for public buildings;

- carpool, van-pool, and public transportation programs;

- energy efficiency standards and policies to govern procurement practices of the state and its political subdivisions;

- thermal efficiency and insulation requirements for new and renovated buildings;

- a traffic law permitting, where practicable and safe, right turn on red lights.

\section{G. Environmental Protection}

While many individuals argue that current energy and economic problems make it imperative that states slow, or sacrifice, the march towards improved environmental quality; few of the region's member states have evinced an overt willingness to compromise environmental goals.

In general, air and water policies might be summed up as improving quality and limiting (eventually halting) undesirable discharges and 
emissions. While there is recognition that incremental improvements in control become increasingly, and ultimately prohibitively, expensive each state seeks to determine its own balance between constricting the economy and protecting the environment. The problem in establishing levels of control is essentially jurisdictional: a desirable level of control or regulation from a state's viewpoint may not match that of federal regulatory agencies. Where the regulatory agency essentially preempts authority, as the Nuclear Regulatory Commission does for nuclear power, the state cannot always achieve the level of control it desires.

Despite this, many state and federal prograns llay effect a cliage in the manner in which state environmental goals are attained. of the more promising programs, land use planning initiatives could have the most comprehensive impacts. With the exception of Vermont, all states in the region participate in the Coastal zone Management Program run by the Department of Commerce. Attainment of a management plan accepted by the secretary of the Department of Commerce, after federal review, will commit federal agencies to the development and protection strategy.

Vermont, the only interior state, led the region in land use planning initiatives with its Act 250. Though the land use plan has not been accepted by the Leqislature, the information the planning process has developed and the permitting procedure the Act created have helped to check uncontrolled development in the state. The Rhode Island State Planning office (in conjunction with federal, state, and regional agencies). has also developed a land use plan, in this case one acceptable to the state legislature. The Maine legislature has also passed legislation affecting land use: the site Location of Development Act finds that some forms of development, because of their size or nature, can damage the natural environment and that, rather than leave the location of developments to their owners, a public authority (the Bureau of Land Quality Control) should have the power to regulate.

Whether state executive agencies and legislatures can anticipate the potential impacts of new (to the nation, region, or state) energy technologies is a matter of some concern. Can Rhode Island and 
Massachusetts provide the level and type of regulation necessary to develop Narragansett coal deposits without untowardly damaging the environment? Will the states be able to develop the policies necessary for control of emissions from waste burning power plants? Will Maine ensure adequate protection against erosion and loss of soil quality if the state chooses to implement large scale wood utilization systems? What are the coastal affects of tidal regulation at Passamaquoddy? What new information must be developed to ensure the compatability of such projects with current environmental standards and goals? The variety of novel energy strategies being considered by state policy makers promises to stress the need for improving environmental analysis and regulatory capability at the state level.

\section{H. Consumer Issues}

Consumer participation in energy related affairs has increased extensively over the past three years. A number of voluntary and statutory public interest groups (for example the Public Interest Research Group (PIRG) and the office of consumer council in the Connecticut Public Utilities Control Authority respectively) have developed the energy expertise and legal technique necessary to represent consumer interests at administrative, legislative, and judicial hearings. The large majority of consumer issues have fallen into three general categories: rate increases, utility practices, and rate structures.

Each state in the region has at least one rate hike request pending, and several have more than one. In addition, at least one state, Connecticut, has seen an electric utility request a rate hike before controversy over a preceding increase had died out. While acknowledging that rate increases based on increased fuel costs are justifiable, utility commissions are having a difficult time explaining problems similar to that which occurred in New Hampshire and Connecticut. In one case the Public Service Co. of New Hampshire was ordered to repay $\$ 4$ million it had charged customers for unburned coal. In the second, a number of municipal utilities lodged five challenges against the Connecticut Light and Power Co., including challenges of three revised rate schedules $(R-1, R-2$, and $R-3)$, a fuel adjustment charge levied iń 
1971 and 1972, and an anti-trust suit. The fuel adjustment charge was settled, the $\mathrm{R}-2$ rate was subject of a Federal Power Commission ruling requiring $C L \& P$ to refund $\$ 1$ million to the municipal utilities, and the remaining three cases are pending (Bulletin, Norwich, Conn., October 2, 1976). Whether the refunds will be passed on to consumers will depend on the municipal utilities policies.

Concern over atility economic practices and electric rate structures is envinced throughout the region. Experiments with peak demand pricing in connecticut and Vermont have attracted considerable attention, as has a flat rate initiative petition on the Ballot in Massachusetts, voted down in November's election:

\section{UNIFORM ELECTRIC RATES}

Law proposed by initiative petition which was disapproved by the House of Representatives.

Utilities presently charge large users of electricity a lower rate per kilowatt hour than small users. The proposed law would require that every electric utility company charge a uniform rate per kilowatt hour of electricity to most customers. Excepted from this general rule would be rates charged to other electric utility companies and to residential customers who heat their principal place of residence by electricity. The law would permit a different rate to be charged to residential customers for the first three hundred (300) kilowatt hours they consume each month. It would also allow "peak load" pricing whereby a higher rate could be charged during the periods of the day or seasons of the year when consumption of electricity is the greatest. The act would authorize the Department of Public Utilities to issue implementing rules and regulations, and it provides for enforcement.

Though the Uniform Electric Rates petition is opposed by industry and Governor Dukakis the fact that Massachusetts Fair share has managed to gather over 100,000 signatures on the initiative petition reflects consumer concern with rates.

I. Public Power

Public power, in the form of municipal utilities, is generally accepted in the region. Speculative energy development, such as the, 
solid waste facilities in Rhode Island, Connecticut and Massachusetts are being financed as public power facilities (that is through state bond issues). Several municipalities (as noted in section $E$ of this chapter) have met opposition in attempting to develop municipal hydroelectric facilities. Only in Massachusetts has a state Power Authority been proposed. Though disapproved by the House of Representatives the initiative petition received enough public support to be placed on November's ballot but not enough ballot support to bring about reconsideration:

\section{MASSACHUSETTS POWER AUTHORITY}

Law proposed by initiative petition disapproved by the House of Representatives.

The proposed law would establish a Massachusetts Power Authority with seven members appointed by the Governor to staggered six-year terms. The Authority would establish and operate a system to supply electric power to utilities throughout the commonwealth with minimum adverse impact on the environment. The Authority would be required to engage in research and development of new sources of power, new siting techniques, and methods of environmental protection.

The Authority would build and operate all new generating and transmission facilities in the Commonwealth and could purchase existing facilities through eminent domain. The Authority would finance its activities by issuing tax exempt revenue bonds.

The Authority would be required to develop and update annually a 20-year demand study and siting plan within 18 months of its incorpora= tion. Before a facility could be constructed, it would have to be approved by the Governor and the community in which it is to be located.

The Authority would be exempt from taxation but would make payments in lieu of taxes to cities and towns in an amount equal to the tax which would be paid if the Authority's property were owned by a private electric utility.

The Authority would be forbidden from doing promotional advertising. Employees of utilities displaced by activities of the Authority would have first preference in hiring.

If a city or town should vote to establish a municipal lighting plant and to acquire the 
facilities of the utility then serving their community, and if the utility should refuse to sell, the Department of Public Utilities would establish a fair price for the facilities which the utility would be required to accept. 
APPENDIX A

\section{A New England Energy Policy}

New England Regional Commission

November 7, 1975 
New England recognizes that the national goal of energy independence is aimed at ensuring stable, long-term supplies of fuel at reasonable prices to meet a level of energy growth consistent with long-term economic, social, and environmental goals. New England has a strong interest in that goal because it has the greatest vulnerability to international oil price and supply manipulation. Continued heavy reliance upon imported oil with its consequent, disproportionate regional energy cost will further undermine the economic base of this region and, therefore, cannot be borne.

Therefore, the region of New England is prepared to commit itself to the development of a more nearly balanced mix of energy production capabilities, including nuclear power facilities, hydroelectric and other indigenous resources, domestic oil and gas resources, and the use of coal and other alternative fuels. To that end it has established fuel-use goals to be achieved during the next decade to reflect that balance and to reduce the region's dependence upon oil by one fifth.

In this effort the states of New England are well aware of the necessity to coordinate various technological and institutional aspects of energy resource development within their region and to join that development to the national framework.

1. This coordination has already gained momentum through state participation in energy-related activities at the New England Regional Commission.

2. This coordination has been communicated to the national level by means of joint meetings between representatives of the Fcderal Energy Administration and of the states and the New England Regional Commission.

3. We emphasize that successful communications of this sort are essential to the creation of a regional energy implementation plan which enhances lhe capabilities of the states to contribute to a regional 
and national energy framework, while increasing the responsiveness of the nation to those particular needs of the region for sound economic development.

4. Continuation of this effort, to which the region is committed, should result in a deliberate, realistic regional energy policy.

Recognizing the need for immediate and intermediate steps, the New England Region is prepared to deal with the following areas:

1. conservation;

2. nuclear energy;

3. outer continental shelf development;

4. coal conversion;

5. hydroelectric and other indigenous resource development; and

6. alternative energy sources--research and development.

\section{Conservation}

The New England Region, of all the regions within the United States, has attained an unequaled record of energy conservation. It has recorded a 20 percent conservation effort in stark contrast to a 5\% conservation effort recorded in the remainder of the nation.

1. The region is committed to a continued effort of conservation in a systematic and concerted manner and on a regional basis.

2. The establishment of strong quantitative goals and a comprehensive implementation plan commensurate with respective state capabilities will have the highest immediate priority within our region.

\section{Nuclear Energy}

The existing base of nuclear generating capacity in New England is far in excess of any other region within the United states. Ilowever, the region recognizes the role of additional nuclear capacity in meeting future requirements, mindful of the continuing need for the pursuit of plans for disposition of nuclear wastes. 
1. To this end, the region will participate in concert and in equal partnership with the Nuclear Regulatory Commission regarding the evaluation and siting of nuclear facilities.

2. The region will work for the establishment and creation of a regional institution which will plan the implementation of power generation jointly with private and/or public utilities, dependent on the system in the individual states.

3. The region will work as an equal partner with the Nuclear Regulatory Commission in regulatory and licensing prnnerures to eneurc cxpeditious ald safe handling of radioactive materials and wastes and mutual1y satisfactory construction and operation practices.

OCS Development

Inasmuch as the Federal Government has recognized the need for a national policy with regard to Outer continental shelf as a potential site of energy resources, including both natural gas and oil, the New England region stands ready to participate fully with the Federal Government in that endeavor, and in the pursuit of regulations and guidelines to protect the coastal shore line.

The proximity of the New England region to Canada emphasizes the desirability of a close wnrking relationchip in the develupment of the outer continental Shelf.

The New England region has the capabilities to:

1. Provide sites for refineries and other facilities so that the potential resources of the outer rontinental shelf can be processed economically to meet both the regional and national needs for energy resouraco, and

2. Review the development of facilities to accommndate ocs service and support industries.

\section{Coal Conversion}

Recognizing the overall dependence upon imported oil for the generation of electric energy by the utilities within-the New England Region, the Region affirms its position: 
1. To convert existing oil-fired facilities to coal within a time frame adequate to guarantee implementation that is economically feasible.

2. To review and aggressively pursue the economic viability of new fossil-fuel energy production facilities with the private sector; and

3. To cooperate with the Federal Government in resolving coal transportation problems caused by the incapacity of the northeastern railroad network.

Hydroelectric, Solid Waste, and Other Indigenous Resource Development

Recognizing the imperative of pursuing all possible sources of energy, the New England Region affirms its position:

1. To support the expeditious implementation of feasible hydroelectric, including tidal projects;

2. To support the use of wood for power generation, where feasible; and

3. To continue the discussions and negotiations concerning the purchase of surplus energy from the Eastern Canadian Provinces as it is developed.

4. Recognizing the potential value of energy recovery from solid waste, New England will undertake to develop facilities from solid waste recovery and conversion to energy.

\section{Alternative Energy Sources--Research and Development}

Recognizing the immense resources available within the New England region in terms of technical competence in research and development, financial institutions, and creativity, the New England region affirms its intent to pursue the research capability and development technology for solar and other alternative energy resources. To this end New England will:

1. Establish, within our institutions of higher learning, a priority for the development and marketing of alternative replenishable energy sources, e.g. , sular, wind, and wood for practical and widespread consumption;

2. Encourage and marshal venture capital in the private sector for the marketing of alternative energy resources; and 
3. Provide tax and financial incentives for utilizing solar and other alternative forms of energy.

\section{Economic Implications}

The New England Region recognizes the regional and national imperatives which address the issues of its economic viability and its land use patterns, as well as its quality of life. The Region further recognizes that its declaration of principles cannot be achieved without the full cooperation of the national. government. As individual states, as the regional entity of New England, and as part of our nation's Federal system, we recognize the different roles we must play and the different stewardships we must discharge.

However, the changes in fuel consumption implied by the previously described targets will themselves generate large capital costs throughout the region. The funds necessary to finance these changes have historically and are currently diverted to high fuel costs. Therefore, only some short-term relief from high energy prices will make possible the capital formation necessary to achieve those energy-use targets.

The commonality of energy as a fundamental base of our society, he it the Statc, the Region, ur the Nation, is inescapable. The responsiblities which we hold separately as well as collectively require action in concert as well as in variation within a central theme. To address the energy issue jointly, to act collectively in the pursuit of itc oolution--this ib the affirmation of the New England Reqion. 